\title{
Saatekirjaga rahvaarsti juures ${ }^{1}$
}

\begin{abstract}
Mare Kõiva
Teesid: Artikkel vaatleb Laine Rohu, Lõuna-Eesti tuntud rahvaarsti 1980. aastate ühte ravimisstrateegiat: ta nõudis vastuvõtule tulevatelt patsientidelt arsti saatekirja. Selline käitumine oli tingitud sovetlikust rahvameditsiini võtete keelustamisest, millele vastuseks ravija demonstreeris, et teeb koostööd kutseliste meedikutega. Saatekirjad ja arstimise kirjalik külg kujutab endast huvitavat folkloorset ja psühholoogilist uurimismaterjali. Artikkel vaatleb saatekirjaga saabunud patsientidele kohaldatud ravimisrituaali, diagnoose, millega patsiendid pöördusid, arstide ja patsientide päritolu, trükiste ja kirjalikkuse osa 20. sajandi ravija traditsioonis ja tema ravirituaalis. Ühtlasi iseloomustatakse ajastukohaseid meediakuvandeid ravijast ja meedia osa ravija tuntuse alusena.
\end{abstract}

Märksõnad: alternatiivmeditsiin, Laine Roht, rahvameditsiin, rahvaravitseja, ravitsemisriitus, saatekirjad

Artikkel jätkab sovetiaegse meditsiinisüsteemi äärealade vaatlemist, seekord Lõuna-Eesti tuntud rahvaarsti Kaika Laine 1980. aastate ravimistrateegiate näitel. Just sellesse perioodi jääb Kaika Laine (kodanikunimega Laine Roht) avalik teadaanne, et ta võtab vastu üksnes arsti saatekirjaga patsiente. See teade viitas otsekui toimivale meditsiinisüsteemide-ülesele koostööle ja oli omas ajas intrigeeriv märk meditsiinis toimuvatest muutustest.

1980. aastatel pöördusid Nõukogude Liidus rahvaarstide poole tavaliste patsientide kõrval tuntud ja kõrgel ametipositsioonil olevad isikud, samuti poliitikud. ${ }^{2}$ Olen käsitlenud seda rahvaarstimise külge üldjoontes 1995. aastal ilmunud artiklis "Loitsust riituseni" (Kõiva 1995), ent mitmetahulist nähtust on toonaste staarravijate näitel põhjust kindlasti uuesti vaadelda. Seda enam, et N Liidu eksisteerimise viimastel kümnenditel oli foto-filmi-videodokumentatsioon laialt levinud ja kättesaadav. Kuulsuste ja poliitikute ravimist omistati 1980. aastate Nõukogude Liidus näiteks legendaarsele Gruusiast Moskvasse asunud Džuna Davitašvilile ja Bulgaarias resideerunud bulgaaria-makedoonia 
taustaga pimedale prohvet Vangale. D. Davitašvili ravis enda ja meedia väitel NLKP Keskkomitee peasekretäri ja NSV Liidu Ülemnõukogu presiidiumi esimeest Leonid Brežnevit ja Venemaa Föderatsiooni presidenti Boriss Jeltsinit, Gruusia presidendi Ševardnadze perekonda, samuti oma aja kuulsamaid kunstiinimesi. Vanga sidemetest Bulgaaria ja Vene Nõukogude valitsejatega ja osalemisest tema võimete määramise katsetel on korduvalt kirjutatud (nt Valchinova 2007). Tuntud isikute seesugust ravipraktikat kajastasid kuulujutud ja erakordselt võimekad alternatiivravijad muutis nähtavaks meedia. ${ }^{3}$ Kuigi kuulsused moodustasid väikese osa ravialustest ja külastajatest, avas see uusi võimalusi. Meediakuvandi olemasolu mõjutas eeldatavalt dialoogi kogukonna ja patsientidega, rääkimata suulisest suhtlemisest, esinemistest-loengutest laiemale huviliste ringile. Kahtlemata vajab niisugune sotsiaalsete, kultuuriliste ja võimuga seotud seikade ajastukohane sümbioos sotsialismi-perioodil lähemat faktipõhist analüüsi, ent ühte ja teist selgub ka eesti ravijate materjalidest. ${ }^{4}$

Kaika Laine otsus nõuda saabujatelt saatekirja põhjustas silmanähtava surve arstidele. Arsti litsents ei lubanud selliseid saatekirju välja kirjutada, patsiendi saatmine väljapoole meditsiinisüsteemi oli illegaalne ja seadis ohtu arsti ametitunnistuse. Ent patsientide palve peale võttis siiski osa arste riski ja saatis oma ravialuseid saatekirjaga rahvaarsti juurde konsultatsioonile või ravile. Sellise käitumise taga aimuvate motivatsioonide hulka kuulus soov patsienti abistada, vastutulek tema tungivale soovile pääseda alternatiivsele vastuvõtule, aga arvatavasti ka teistsuguse süsteemi efektiivsuse tunnustamine. Rahvaarstile tähendas saatekiri muu hulgas enesekaitset sovetliku süsteemi vastu. Oli ju rahvaarstina tegutsemine omaalgatuslik, keelatud või lausa karistatav - pealekaebamise korral ootas mitteametliku meditsiini võtetega arstijat kohtulik karistus. ${ }^{5}$ Kuivõrd pinges oli näiteks Kaika Laine selliste kaebuste tõttu, osutab ühe tartlase kirjapanek. Ühtlasi seletab see saatekirjade nõudmise põhjuseid:

[---] 1983. a. mais oli kirjutatud Laine Rohi peale kaebekiri: "Petab rahva käest raha välja ja remondib sellega oma maja." Selle peale keelati tal kohalike võimude poolt ravimine-loitsimine ära, miilits oli mitu korda kontrollimas käinud. Kohapeal peetakse üheks põhjuseks järgmist lugu: L. Rohu lähemas naabriperes oli lapsel nahahaigus, millele arstidelt abi ei saanud. Vanaema oli lapse salaja viinud Laine juurde ja haigus oli paranenud, laps terveks saanud. Lapse isa, juhtival positsioonil olev mees, materialistliku maailmavaatega, sai sellest teada ja oli solvunud. Oma pahupidipööratud tänutundes oli organiseerinud kaebekirja.

Haiged aga tulid ikkagi. Alati seisis värava ees mõni auto, nädalavahetusel ja pühade ajal terve rodu. Oli neid, kes äraütlemisele vaatamata ööbisid autos, lootes, et neid järgmisel päeval vastu võetakse. 
Pilt 1. Rahvaarst Laine Roht Kaika külast. Võru teeninduskombinaadi fotost tehtud koopia. ERA 14352.

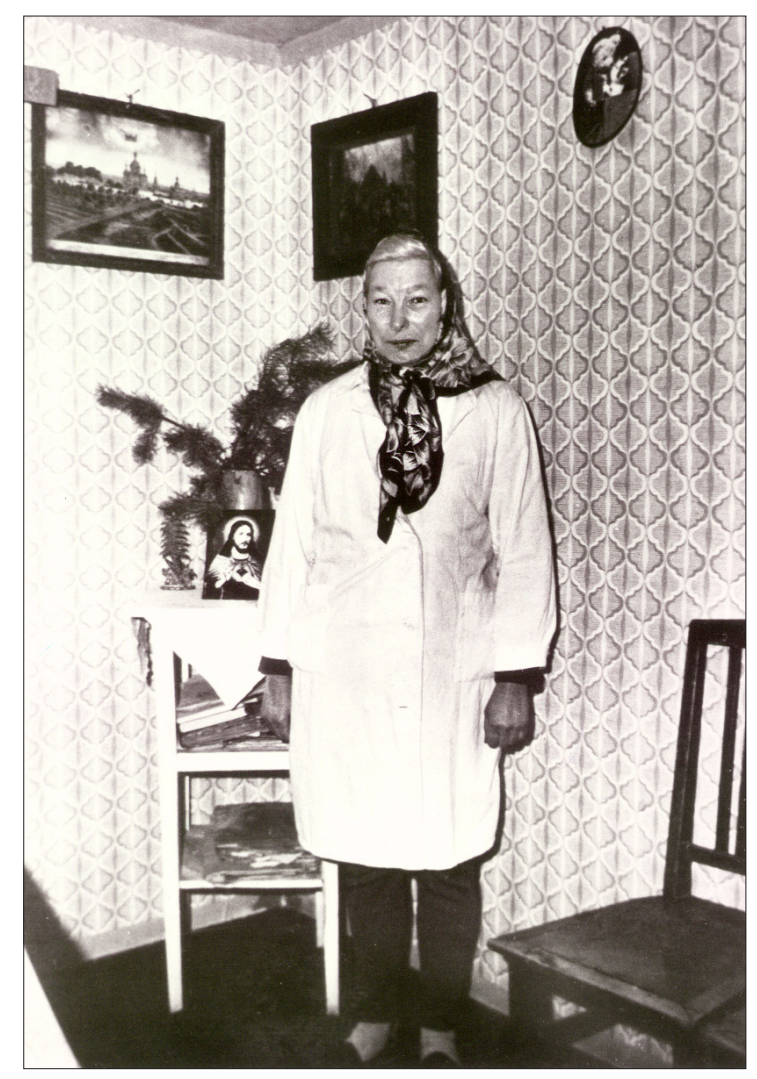

Mina läksin Kaikale 1983. a. augustis, et abi saada oma 22 aastasele pojale, kellel on epilepsia ja lööve peanahal.

Jutulesaamine oli keerukas, imearst oli tõrjuv ja kartis miilitsaid. Olime Võrumaal kaks nädalat, enne kui mitme vahendaja kaudu sinna saime.

[---] Järgmisel aastal oktoobripühade ajal läksin Kaikale üksinda. Autode rida maja ees oli tohutult pikk, väravad kinni ja kedagi vastu ei võetud. Oli jälle pahandust ja kaebamist olnud. Pooletunnise ootamise järel tuli mees värava juurde ja teatas, et kedagi vastu ei võeta, sõitku kõik minema. Palusin kokkusaamist, sest mul oli midagi üle anda. Tuli, aga oli väga muutunud. Samm tönts ja vanainimeselik, näost tursunud, nina oli marraskil, pea mitme rätiga mässitud. Hakkas üle aia nutuse häälega rääkima, et jälle teda kiusatakse. Ta olevat mitme inimesega Aili Pajule sõna saatnud, aga see pole ikka talle appi tulnud. Tal on kõrge vererõhk ja pahandused on ta haigeks teinud. Palus, et ma omakorda 
A. Pajule teataksin, mida ma ka tegin. [---] (RKM II 427, 290/5 < Tartu 1 - Inge, s 1928 < päevikumärkmete põhjal (1986).)

Kaika Laine väitel võtsid Võru arstid temalt pärast seitsmeteistkümne kirja (eespool tsiteeritud kaebekiri 1983. aastast) ära 1982. aastal Brežnevilt saadud ravimisloa, see jäi kehtima vaid Tartus ja Tallinnas.

[---] 1982. a. sai Laine R. ravimiseks Brežnevi loa Moskvast. Talle anti ka valge kittel. Sellest ajast näitas ta meile fotot. [---] (RKM II 454, 419/98 < Karula khk, Kaika k < Urvaste khk - Rain Mikser, Agne Sisask, Karin Tamm, Tõnu Tender (1992).)

Koostöö teadlaste ja rahvaarstide, arstide ja rahvaarstide vahel mõnevõrra toimuski. ${ }^{6}$ 1980. aastate mitmepoolsetest intervjuudest ilmneb, et katseid ravijatega ja koostööd nendega tegi nt biokeemik Aili Paju, põllumajandusakadeemia (maaülikooli) juurde koondunud mitteformaalne rühm Neeme Karolini eestvõtmisel, sama ülikooli õppejõud Rein Muoni ja teised uurijad (vt Kõiva 1995; Vigala Sassi intervjuud folkloristika osakonna digitaalses arhiivis; Paju 1998). Arhiiviteadetest leiab Kaika Laine kohta sedastusi:

[---] Tartust käisiva sääl prohvessori (RKM II 397, 454 (43) < Võnnu khk, Lääniste k - Eda Kalmre < Salme Nagel, 66 a. (1986));

[---] Laine Rohuga teevad koostööd ka meditsiiniprofessorid; [---] ja [---] Arstid (Tallinna haigla peaarst - millise, ei öelnud) teevad Lainega koostööd. [---] (RKM II 454, 419/98 < Karula khk, Kaika k < Urvaste khk Rain Mikser, Agne Sisask, Karin Tamm, Tõnu Tender (1992).)

Arvan, et saatekirja küsimine oli osa rahvaarsti mimikrikäitumisest, et olla vastuvõetav riiklikule süsteemile, olla kaitstud repressiivse süsteemi eest või sellele nähtamatu. Eespool toodud näited osutavad, et side teadlastega kestis kümneid aastaid, vajadusel otsiti neilt toetust muude võimaluste kõrval ka hapra suulise sõnumi vahendusel.

Saatekirjaga saabunud patsientide kõrval vaatlen Lõuna-Eesti arstija ravimisrituaali kirjalikkusega seotud külgesid ja saatekirja loovutanud arstide ja patsientide päritolu. Kuna tänapäeval on meedia üks olulisemaid mõjutajaid ravija imago loomisel ning Kaika Laine maailmavaate ja raviviiside tutvustamisel ja tema tuntuse tõstmisel on olnud meedial olulisim roll suuliste võrgustike kõrval, siis iseloomustan ajastukohaseid meediakuvandeid ravijast ja meedia osa ravija tuntuse alusena. Lühemalt vaadeldakse trükiste osa ravija traditsioonis ning salapäral ja usul põhineva arstimisviisi toimes. 


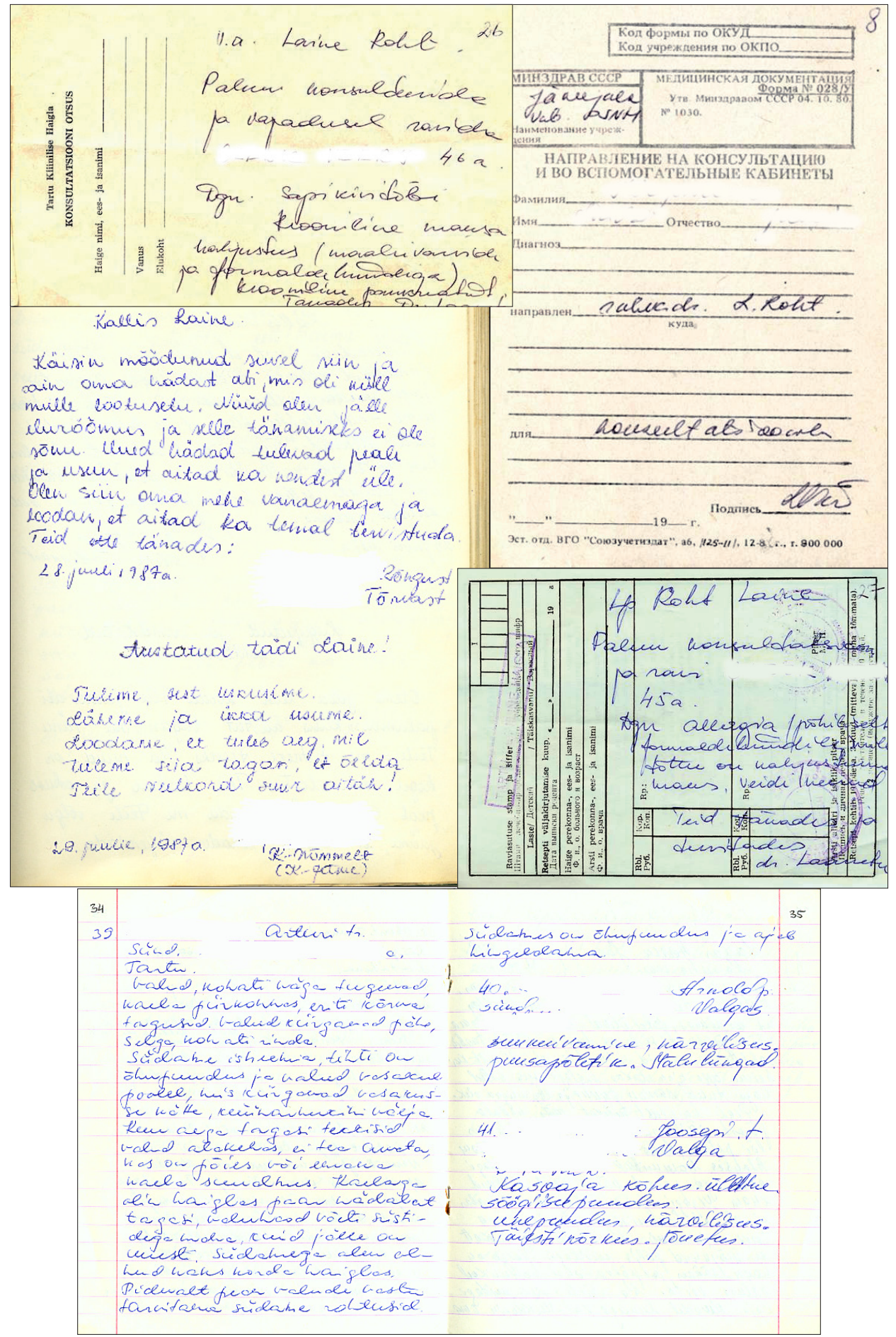

Pilt 2. Saatekirjad, väljavõte külalisteraamatust (keskel vasakul) ja väljavõte patsientide registreerimise vihikust (all). 


\section{Allikad}

Analüüsi aluseks on Lõuna-Eesti rahvaarsti Kaika Laine (Kaika nõia) arhiiv, mis sisaldab patsientide narratiivide ja muude materjalide seas arstide saatekirju, mille patsiendid said rahvaarsti külastamiseks. Artikli jaoks on kasutatud Eesti Rahvaluule Arhiivi nimelisse kogusse "Laine Roht" edastatud saatekirju ja tänuraamatuid. Lisaks on vaadeldud sama perioodi registreerimisraamatut, kuhu patsient või rahvaarsti abiline kirjutas isikuandmed ja visiidi põhjuse. Samad käsikirjad sisaldavad vahel rahvaarsti (patsiendile nähtamatuks jäänud) arvamust haiguse kohta. Üheks allikaks oli nn külalisteraamat ehk tänuraamat, kuhu patsiendid kirjutasid oma tänusõnu, kirjeldasid korduvaid visiite ja edukaid tervenemisi. Lisamaterjalina olen kasutatud oma intervjuusid ja tähelepanekuid erinevatelt külaskäikudelt aastail 1983-1999, kohtumistelt konverentsidel ja rahvameditsiini-teemalistel foorumitel; samuti Laine Rohu kohta avaldatud trükiseid. Laine Roht oli üks rahvaarstidest, kellega kohtusin korduvalt. Ta oli omapärane isiksus, mistõttu tundus tema puhul tähtis jäädvustada märkimisväärse ravija tegevust ja koguda arhiivi temaga seotud materjale laiemalt kui see folkloristikas tavaks oli. See tegevus viis mind kokku teiste huvilistega, ajendas saatma üliõpilasi tema juurde jäädvustama ja uudsemaid küsitlemisvõimalusi katsetama. Tõnu Tenderi rühma käik oli just täpsema küsitlustehnika ja eksperimentaalsuse mõttes oluline (vt ka Tender 1992).

\section{Elukäik ja arstimisviisi iseloomustus}

Laine Roht (4. mai 1927 - 21. aprill 2013) oli laiemalt tuntud Kaika nõia (ka Haabsaare nõid) või Kaika Laine nime all. Tema arstijanimi on seotud tänaseni püsinud rahvapärase tavaga tituleerida rahvaarste kohanime ja staatusenimetusega nõid; teine aga esindab samuti tüüpilist rahvapärast nimeloome mudelit, mis koosneb külanimest (talunimest) ja eesnimest. Kaika Laine elukoht asus Lõuna-Eestis Kaika külas, Püssa talus. Tema perekonnas ja hõimus on ka varem olnud rahvaarste (vanavanaema ja isa), kuid leidub ka kutselisi meditsiinitöötajaid:

Mu isa oskas teha massaaži ja oskas arstida loomade haigusi. Ta ravis näiteks hobustel nikastusi ja muid haigusi. Ja võttis vasikaid vastu. Tal oli asjandus, millega ta sai loomi kutsuda. Teda kutsuti kohale, kui oli jalaluu nihestus. Peamised ravimid olid tal tärpentin, viin, kondiõli. Meie vanavanaema (vanaema ema) oskas ka ravida. Ta võttis lapsi vastu (Kõiva 1990). 


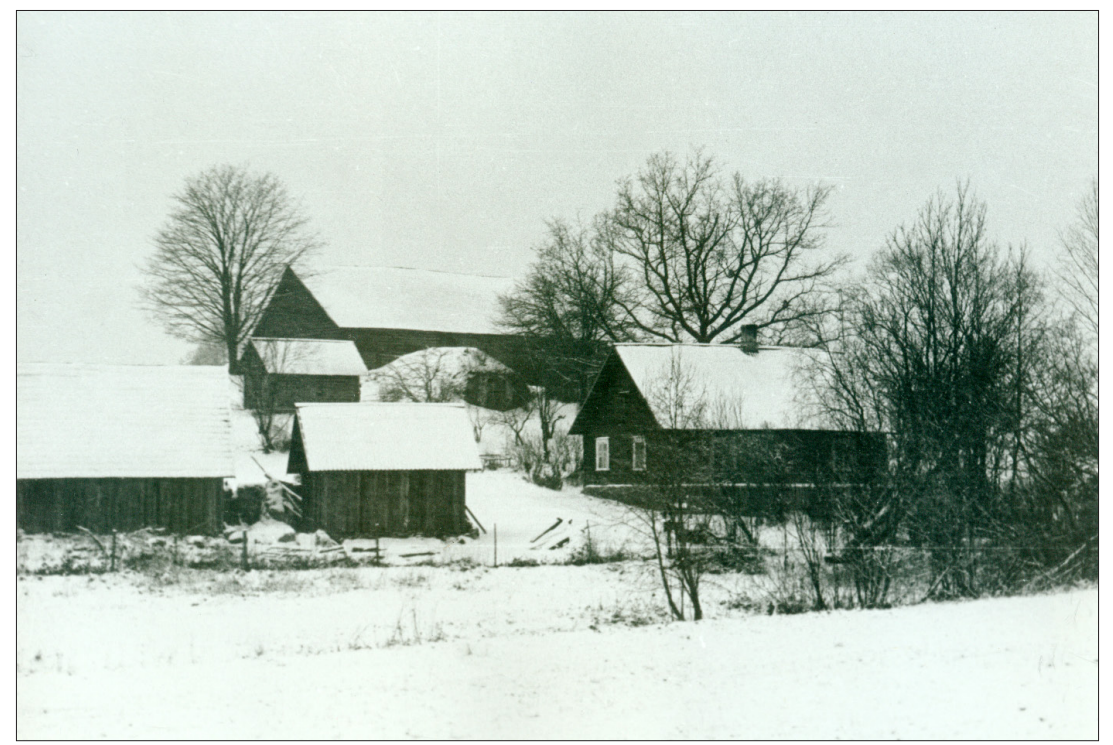

Pilt 3. Rahvaarst Laine Rohti elukoht Kaika külas Püssa talus (Karula khk). Foto: Ain Raal 1981. ERA 14351.

Sündimisel märganud ämmaemand ja ravitseja Kadi Aab lapse otsaesisel arsti märki - madu karikaga (intervjuud 1990, 1992, Poll 2004: 16), väljavalitus ja sünnipärane anne oli tähtsal kohal Kaika Laine enesekuvandis. Otsest väljaõpet ta siiski kelleltki ei saanud, ei meditsiini ega rahvapärase ravimise alal. Ta lõpetas Kaika 6klassilise kooli ja töötas 1950. aastast postiljonina, vedades küladesse kirju, perioodikat ja postipakke. Postiljoni amet oli tervisele kurnav, kuid samas tundis ta selle tõttu hästi kohalikke inimesi. Oma elu veetiski ta isamajas, mis paikneb Lõuna-Eesti kuplilisel maastikul. Hajakülas paikneva 1930. aastate stiilis puumaja juurde kuulus laut, hoiupaigad, kelder, hiljem lisandus mäeküljele ehitatud kamin. 1983. aastal oli majapidamine üsna lihtne, moderniseerumine toimus järkjärgult ennekõike Eesti Vabariigi ajal:

Elumaja on lihtne, väike, peaaegu ilma vundamendita, hiljuti väljast remonditud ja rohuroheliseks värvitud. Maja on ümbritsetud paljude metsa- ja viljapuude ning põõsastega. Silma paistavad lopsakad humalapõõsad. Majapidamisõues hulgaliselt suuremaid ja väiksemaid kuudikesi, küll üksteise kõrval ja peal. Kuutide katustel jookseb sõbralikult haukudes hundikoer. Aed on ümbritsetud madala taraga, millel kaks lukustatud väravat, üks maanteepoolsel küljel, teine vastaspool. Tara 
kohal, umbes $3 \mathrm{~m}$ kõrgusel on teine piire, justnagu eraldamaks ka selle kodu õhku muust maailmast. Selleks on kasutatud peenemaid puulatte, mis seotud ühe kasvava puu küljest teise külge. Lageda koha peal on järjeks kasutatud teivast. [---]

Niipalju kui esikust läbi minnes nägin, oli maja seest äärmiselt lihtne, askeetlik ja hall. Vastuvõtutoas oli väike piklik laud akna all, kaetud heledat tooni linaga, laual aaloepott (L. R. ütles "aaloelilleke"). Peale selle 3-4 lihtsat tooli. Väike aken oli kärbsemustast tihedalt täpiline ja kärbseid oli rohkesti. Kärbsed lendasid hääletult, aeglaselt, nagu ujudes ja kui käele või näole laskusid, siis kõdi see ei tekitanud, nii et polnud mingit vajadust neid ära ajada. L. R. ütles, et ta ei tohi kärbest ega ühtki elusolevust tappa, ta peab elu soodustama ja hoidma.

Maja on elektrita, elekter pidi segama loomulikku olekut. Seinad olid täis pilte. Näis et suurem osa neist olid patsientide kingitused, tehtud isetegevuslase käega, maastikud ja loomade pildid. Peale selle veel ajakirjadest väljalõigatud trükised, ikka loomad ja linnud, segamini kitšilikud ja kunstilise väärtusega. Nii näiteks oli seal trükis Ilmar Malini maalist "Linnud". (RKM II 427, 290/5 < Tartu l - Inge, s 1928 (1986).)

Laine Roht oli lastetus abielus, lesestus vara, vanemas eas elas Kaika Laine juures vennapoeg elukaaslasega, kellest kujunes igapäevase praksise assistent (vt lähemalt Ellermaa \& Pitsner 2013). ${ }^{7}$ Varem abistasid teda patsientide vastuvõtmise juures mitmed juhututtavad, eeskätt samasugused arstijad või selle ameti poole püüdlejad (intervjuud 1990, 1992 jm). Ühtlasi vahetas Kaika Laine visiteerivate või nn õpivisiidil alternatiivravijatega arstimisteavet. ${ }^{8}$

Ta alustas arstimist 33aastaselt, mida ta ise pidas märgiliseks vanuseks. ${ }^{9}$ Kaika Laine kuulsus kasvas aastatega, esmalt kodukandis, kuid temast sai kiiresti üle Eesti tuntud isik. Just 1980. aastate alguses levis kulutulena suust suhu kumu tema arstijavõimete kohta. Teati, et ta arstib arhailiste meetoditega: ta soovitas patsientidel võtta kaasa vett või viina, suhkrut/mett, soola või rasva. Kaasatoodud ainetele luges ta peale palved ja loitsud. ${ }^{10}$

Kaika Laine ravimeetodid kuulusid traditsioonilise rahvameditsiini klassikasse, alates taimravist, tavast lugeda toodud ainetele peale palveid ja loitse, kuni soovituslike ainete endini, mida loitsu ja rituaaliga muudeti ravimiks. Innovatsioonina kasutas ta 1980 . aastatel ka akupressuuri võtteid, mille ta omandas ühelt nooremalt ravijalt (Kõiva 1995). Üks püsivamaid ravivõtteid oli taimravi: ta kogus taimi ja valmistas neist leotisi, salve ja tõmmiseid, kuid ta kasutas ka usaldusisikute kogutud taimi - tal oli omalaadne abiliste võrgustik. Kuna Laine Rohul puudus õpetaja, on raviviiside omandamisel olulisel kohal raamatutarkus. On märkimisväärne, et ta õppis näiteks oma loitsud mitte 
külapärimusest, vaid kirjandusest, nt Eesti rahvalaulude antoloogia kolmanda osa loitsude köitest. Sobivaid palveid ja ravimiseks sobivaid pühi tekste valis ta katekismusest, aga kasutas ka kirikukalendrisse trükitud konkreetse päeva kirjakohtasid ja erinevaid väljaandeid (Kõiva 1995). ${ }^{11}$ Intervjuudes räägib ta veel muudest kaasaegsetest trükiallikatest, kust ta loitsusid õppis, nt et hambavalusõnad leidis pioneeriajalehest Säde (Ottas \& Tammer 2000: 40).

Kaika Laine on olnud ka lahke sõnade jagaja. Hiljuti teatas näiteks tuntud telesaatejuht Marko Reikop:

Mul on kogu aeg soojad käed, ma lausa hõõgun, olen selline gorjatši estonski paren. Tundsin ka Kaika Lainet ja hiljuti jõudsid minuni Kaika Laine nõiasõnad. Ta andis enne surma ühele oma tuttavale roseti koos nõiasõnadega, öeldes, et ta annaks need inimesele, kellele tahab anda. See rosett koos sõnadega jõudis kaks kuud tagasi minuni. Nüüd on mul kahe võimsa nõia nõiasõnad (Veidenberg 2014).

Laine Roht kuulus kohaliku kiriku eestseisusesse. Tema 1980. aastate keskpaiga sõnumite hulka kuulus ka teade, et ta võtab vastu ainult kirikus ristitud isikuid. Tol ajal oli ristimise nõue uudne, valdav osa inimestest polnud seotud ühegi kirikuga ja üldjuhul polnud lapsed kiriklikult ristitud. Kaika nõia juurde pääsemiseks ristisid inimesed ennast ja seejärel oma lapsed. Siinjuures pole küsimus, kas inimesed olid usklikud või mitteusklikud, ei ole küsimus ka teaduslikkuses või ebateaduslikkuses, ratsionaalsuses või ebaratsionaalsuses, vaid tervenemissoovis ja ravija nõude usaldamises. Teisalt oli see nõue arstija toetus kirikule, seda usuleigel ajal ning seesugust käitumist hindas ka kohalik vaimulik (Kudu 2009: 91jj). Kahjuks pole sedagi protsessi võimalik täpselt iseloomustada: arhiiviintervjuud ja paarkümmend aastat hiljem meenutatud ja avaldatud mälestused ei ava kõiki tahkusid, kuid võimaldavad sedastada, et nõue teatavate patsientide puhul toimis.

Sis nii ruttu abi es saa, kui laps on ristimata. Üks sõjaväeülem käis kah ja laps oli ristimata, läks ja ristis sis ära. Sellel targal tuleb nagu kohe mingi pilt sellest inimesest ja sellest, mis tal on. Pudeli peale vist või. (RKM II 397, 268 (24) < Võnnu khk, Musta k < Setu - Kadri Peebo < Olga Jänesmäe, 67 a. (1986).)

Samas ei saatnud Kaika Laine patsiente kergel käel tagasi ega vaielnud üldjuhul vastu inimestele, kes väitsid enda olevat ristitud, kuid polnud seda. Sisuliselt võttis ta vastu kõik patsiendid, kuid keeldus siiski näiteks vähihaigetest, kes olid saanud kiiritusravi või opereeritud. 
[K]ui nuga on sehen käinu, sis ei ravi, ütleb, et metalliga on tegemist olnu. Tal om nisukene silm, et nagu läbi näes. [---] (RKM II 397, 455/6 (45) < Võnnu khk, Lääniste k - Eda Kalmre < Salme Nagel, 66 a. (1986).)

Laine Rohu vastuvõtt kujutas endast suulise ja kirjaliku suhtlemise omapärast segu: vestluse ja patsiendi(tide) vaatlemise järel laskis ravija avada kaasatoodud pudelid-topsid, eraldus siis nende ja registreerimisraamatuga teise tuppa loitsima ja rohtusid valmistama. Sel ajal oli ravile saabujatel võimalik tutvuda patsientide poolt kirjutatud tänuavaldustega, samuti omavahel vestelda. Pikema aja pärast naastes õpetas L. Roht arstimi tarvitamist ja tutvustas ravimise juurde kuuluvaid põhimõtteid.

Huvitav oli suhtlemise keelelis-sotsiaalne külg, mis avaneb lindistatud dialoogides: Kaika nõid rääkis vastuvõtul patsientidega kohalikus murdes, mis tekitas silmanähtavalt suurema läheduse Lõuna-Eestist pärit patsientidega, põhja-eestlastele ja kirjakeelsetele inimestele mõjus aga raskesti mõistetava salapärase kõnena. Pealtvaatajana kuulsin, kuidas Kaika Laine armastas oma vastuvõtul kasutada humoristlikku tooni, naljatleda, rääkis patsientidele nende kodukandist pärit tuntud isikutest, kes olid tema vastuvõtul käinud või keda ta oli ravinud. 1990. aastal kirjutab tänuraamatusse Tallinna mees:

Üllatus oli mulle, et tunnete meie suguvõsa kõige huvitavamalt. Tean, et Teilt sai abi minu vanaisa. Nüüd olen mina oma isa ja emaga (Roht 1: 301).

Kommunikatsiooni selline stiil ja ravirituaali ülesehitus mõjus patsientidele rahustavalt ja alandas minu meelest pingeid.

\section{Ravija teekond meedias ja suhted väljaspool kodumaad}

Laine Roht alustas kodukohas ravimist 20. sajandi teisel poolel, kui toimusid olulised murrangud ja muutused tehnikates ja tehnoloogiates, ravimitööstuses, Eestis arenes välja tihe ämmaemandate, velskripunktide ja haiglate süsteem. Suuremad murrangud toimusid ka suhtumises rahva- ja imearstidesse, kellest ei kirjutatud enam külakroonikate rubriigis, vaid kui märkimisväärsetest isikutest, kelle tutvustamiseks ja kelle elusündmuste jäädvustamiseks avanesid lõppkokkuvõttes riigimeedia kõik kanalid. Esmajärjekorras esindas Kaika Laine pärimuslikku meditsiini, ehkki ta omandas tuttavatelt mitmeid uuemaid võtteid, ja kuuldused tema võimatest levisid eeskätt suust suhu suulise suhtlemise teel. Kuigi laiem tuntus ja kaugemalt saabuvate patsientide 


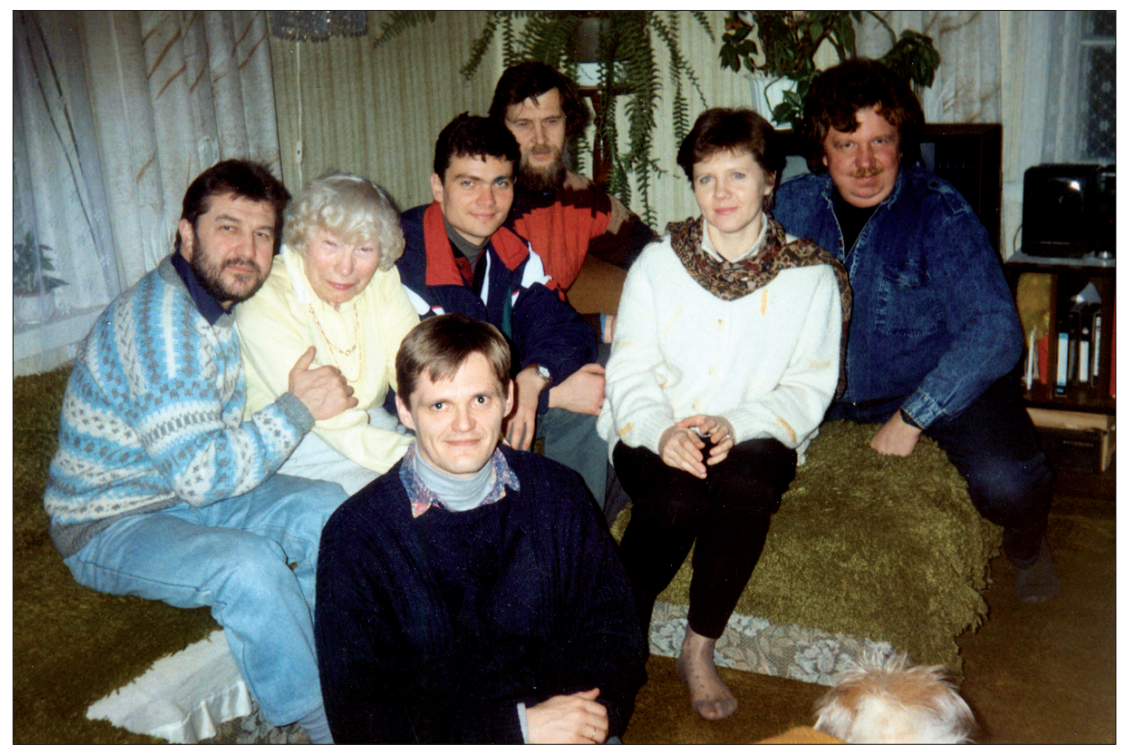

Pilt 4. Televisiooni võtterühmaga poseerimas. Vasakult esimene teleprodutsent Georg Jegorov Kaika Laine kõrval. Foto erakogust.

vastuvõtmine algas 1980. aastatel, kujunes Kaika nõiast meediatäht pikkamisi tolle kümnendi lõpul ja järgmisel kümnendil. Ta esines meelsasti loengutega rahvapäraste ja alternatiivmeedikute ning uusspirituaalsete liikumiste juhte ja teadjaid koondavatel suurfoorumitel, nagu Maaema mess (Kõiva 2015), aga ka ajakirjanduses, sh raadios ja televisioonis. Kaika Laine (ja mitme muu meediumi) esmased tutvustajad enne meediat olid teadlased, humanitaarõppurid ja teda erialasest huvist külastanud isikud. Ka osa Laine Rohu riigikanalite eetris jooksnud saateid ja ajakirjanduse artikleid valmis koostöös folkloristidega, temast kirjutasid humanitarteadlased, kellega tal oli kokkupuuteid (Tender 1992; Kõiva 1993, 1995, 1996) ja muude erialade esindajad. See oli meedia arengus märkimisväärne etapp, kui meediumeid, aga ka teadustulemusi pääsesid tutvustama inimesed väljastpoolt meediakorporatsioone ja -institutsioone. Hiljem olid intervjueerijateks ennekõike alternatiivmeditsiinist, -elulaadist ja -nähtustest huvitatud meediainimesed, osa neist tema patsiendid. Meedia esitles ravija isiksust ja arstijategevust mitme nurga alt, avaldades seikasid elukäigust, selgitusi arstimise kohta ja tema kreedosid. Oma arstimisviisilt ja esinemislaadilt sobis Kaika Laine meediatäheks ja täitma rolli, mille ta ise sõnastas kui "Eesti rahva oma tädi Laine". 
BBC lühiintervjuu vahendusel jõudis ta 1990. aastal ingliskeelse maailma ette kui imearst, ja oli selle üle uhke. Tookordne võttegrupi külaskäik oli mõlemale poolele uudne kogemus. ${ }^{12}$ Võtterühma liikmed lasksid pärast saate salvestamise lõppu oma tervist diagnoosida ja võtsid kuuldut tõsiselt. Mõlemapoolse elevuse tekitas seik, et Kaika Laine märkas meeskonna keskel salajast armastajapaari. See oli otsekui taaskordne kinnitus ravija ja selgeltnägija võimete olemasolu kohta.

Siiski olid rahvusvahelised meeskonnad juhukülalised. Valdavalt olid meediainimesed kaasmaalased, kes sattusid tema juurde alguses koos võttemeeskonnaga, ent külastasid teda hiljem omapead. Mitmega neist arenes lähem tutvus. Kaika Laine kodused albumid, talle kingitud raamatud, fotod ja videod ning salvestused tema igapäevaelust, pidudest ja kohtumistest külalistega annavad seesugustest võrgustikest parima ülevaate, aga lubavad ka sissevaadet tema ellu. Kahtlemata oli see värvikas, erakordne ja vanusttrotsiv eluviis, samas tuleb tõdeda, et kuigi enamik kokkusaamisi olid episoodilised, kujunes neist seikadest paljudele meeldejääv kogemus.

Pärast aktiivsest ravipraksisest tagasitõmbumist meediatähelepanu ei kadunud..$^{13}$ Nagu eespool osutatud, kuulub Kaika Laine rahvapäraste võtetega ravijate hulka, kes on erinevate vaatenurkade alt kultuuriruumi kirjutatud. Ehkki meenutus- ja pühendusraamatud ilmusid teatava ajalise distantsi järel, esitades sissevaateid eelnenud aegadesse, nägi Kaika Laine ära mitmed tunnustusvaldusena mõeldud trükised ja sai osa laiemast austamisest.

Omaette alaliigi kogu raamatutoodangus moodustavad populaarsed ravimisega (ja eneseabiga) seotud raamatud, üks vanu arstiteaduslike raamatute liike, mida on akadeemilises uurimistöös viimastel kümnenditel ühendatud ennekõike uusvaimsete liikumistega (nt Altnurme \& Lyra 2004), ent mis on laiapõhjalisem. Sarnaselt elulooraamatutega vahendavad selliste raamatute koostajad (narratiiviteooria järgi jutustajad vt Jahn 2005; Phelan \& Booth 2005) mh Kaika Laine terviseteemalisi seisukohavõtte, ravimtaimede ja rahvapäraste retseptide teadmust. Heldur Jõgioja $(2008,2009,2010)$ koostatud pretensioonika pealkirjaga raamatusarja Kaika Lainest Vangani pealkirjas kõrvutatakse teda Bulgaaria tuntud imepäraste võimetega prohvet Vangaga (31.01.1911-11.08.1996), kes kuulub koos Maria Trebeniga ${ }^{14}$ Ida-Euroopa tuntumate 20. sajandi ravijate hulka. Niisiis on pealkirja tasemel Laine Rohu isik ikooniline, ehkki seesugustes kogumikes on Kaika nõia elutarkuse õpetused kõrvuti teiste ravijate seisukohtadega (vt ka Ottas \& Tammer 2000). Ülevaateartikliga on Laine Roht esindatud ka vahemikus 1997-2003 ajakirjandusartiklitest kokkupandud valimikus Eesti nõiad (Poll 2004). ${ }^{15}$

Hoopis huvitava diskursuse avab Ellermaa ja Pitsneri menuraamat Kaika Laine inimesed (Ellermaa \& Pitsner 2013), sisuks valik intervjuusid ravija- 
ga kohtunud isikutega. Väljaanne kujutab endast omalaadset arhiivi, teavet selgeltnägija ja ravijavõimetega isiksuse tegevusest tänases ühiskonnas, toob esile tema arstimisviise ja isiksuse jooni, rääkimata intervjueeritavatest, kelle värvikas isikupära konkureerib paiguti nimitegelasega. Umbkaudu kolmandiku moodustavad tuntud inimesed, sh arstid, kellega ta kokku puutus, ning loomulikult sisaldab see edulugusid tervendamisest ja tervenemisest. Veidi ootamatul kombel eenduvad raamatus vananemise ja vanana elamise raskused ning aastad, mil Laine Roht enam haigeid vastu ei võtnud.

Eelnev lühem iseloomustus selgitas, et vahendavate jutustajate (autorite) tööde ja erinevat liiki raamatute kaudu oli Laine Roht kultuuriruumi nähtav osa. Liigilt ulatuvad temaga seotud trükised laiendatud biograafiatest (Kudu 2009) just kirjeldatud populaarsete tarberaamatute ja mälestusteosteni.

Ühes varasematest artiklitest osutasin võrgustikele, mille vahendusel rahvaarstid omavahel suhtlesid ja üritustele, mille käigus lähemalt kohtusid (Kõiva 1995). Need kontaktid ametikaaslastega olid (mõne erandiga) eeskätt Eesti-kesksed. Ühel elamuslikul kohtumisel 1992. aastal oli autoril võimalus koos Laine Rohuga kohtuda soome ravijatega Põhja-Soomes Kaustineni rahvaravikeskuses korraldatud rahvameditsiini konverentsil. Sain kutse esineda ülevaatega ja viia kaasa paar ravijat, kes näitaksid oma võtteid. Kutsusin kaasa erinevate koolkondade ja võtete esindajatena Laine Rohu ja Gunnar Aarma ning kolleeg Mare Kalda, kes abistas Lainet sellel teekonnal.

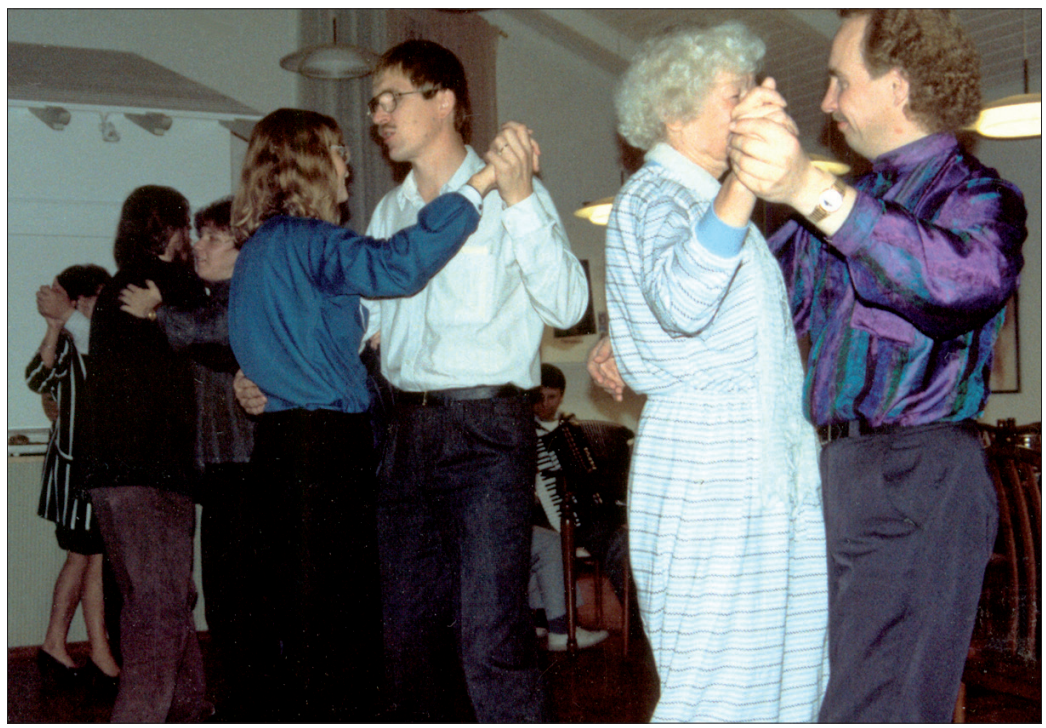

Pilt 5. Laine tantsimas Kaustineni rahvaravikeskuses korraldatud rahvameditsiinikonverentsi ôhtusel koosviibimisel. Antti Hernesniemi foto 1992. 
Mõlema ravija käitumine erines kardinaalselt. Gunnar Aarma luges igal vabal hetkel keskuse raamatukogus, tal olid oma huvialad, selged seisukohad ja demonstratsioonikava. Kaika Lainele oli see esmakordne kokkupuude moodsate mugavustega ja Soome traditsiooniliste ravijatega, kes teenisid igapäevast leiba Kaustineni rahvameditsiini keskuses klassikalise soonetasumise, aadrilaskmise, taimetundmise jm meetoditega. Soome ravijate võtteid sai ta enda omadega võrrelda nii formaalses kui ka informaalses keskkonnas. Umbkaudu 65aastane ravija sai kenasti hakkama igas olukorras, ehkki soomlaste võttestikust enda peal katsetamiseks valitud aadrilaskmisest andis tal füüsiliselt toibuda ja ta ei hinnanud seda kuigi kõrgelt. "Soomlaste võtted on üldiselt samad kui eestlastel ning neil midagi väga erilist pakkuda pole," oli Kaika Laine kiire otsus. Talle oli huvitav kogemus, et raviseansid võoral maal ja kasutatud taimed ei erinenud kuigivõrd kodustest. Temale omaselt sulandus ta seltskonda oma humoorika suhtumise ja valmidusega lõbutseda, tantsida ja tunda ennast staarina.

Kaika Laine on hiljemgi käinud välismaal meditsiini-alastel kohtumistel (Ellermaa \& Pitsner 2013), kuid nendest elamuslikumaks hindas ta bussireise Euroopa usukeskustesse.

Tunnustatud rahvaarstile jätkus tähelepanu kõrge vanuseni ja ka pärast ravimisest loobumist: 80 . sünnipäeva tähistati laiemalt televisioonis ja trükimeedias. Kaika nõid poseeris rahvarõivastes koos televisiooni staarsaatejuhi Vahur Kersnaga, kes oli üks sündmuse peakorraldajaid. Kohalike kõrval olid saabunud isiklikult õnnitlema kunagised patsiendid ja temaga kokkupuutunud inimesed, aga ka nt rahvarõivastes kultuuriminister Laine Jänes. Kuna rahvariiete kasutamine on tänase Eesti rõivastiili kontekstis üsna määratletud kasutamiskoodiga, rõhutas see sümboolselt meie-tunnet, rahvapärast ja rahvakultuuriga seotud ametlikku pidu. Kahjuks pole võimalik pikemalt peatuda ei rõivakoodil ega meediastrateegiatel. Märkigem vaid, et lihtne vanem naine Kaika Laine pole ainuke pikaaegne meedia soosik. Pikalt on olnud meedia tähelepanu keskmes ka eakas Kihnu saarelt pärit laulumeister Virve Köster hüüdnimega Kihnu Virve (s 1928), sisuliselt ravija eakaaslane on samuti pikemalt olnud meedia favoriit. Loomulikult ei jätnud meedia märkimata Kihnu Virve visiiti Kaika nõia juurde, mis meedia rangelt reglementeeritud (kultuuri)uudiste diskursuses on tähelepanuväärne. Märkigem, et elulugude buumi ajal avaldatud elulooraamatus tituleeritakse Lainet pealkirjas näiteks sajandi naiseks (Kudu 2009). Alternatiivmeditsiini propageerija Aili Paju hindas tema raviviise kõrgelt ja kasutas teda osalt teadjanaise prototüübina oma ilukirjandusteoses Teadjanaine (Paju 1994). ${ }^{16}$ Meie tädi Laine brändi esindab nimelise pühenduspingi rajamine tuntud meediapersooni Vahur Kersna poolt, tänuks abi eest kaasinimestele. ${ }^{17}$ 
Pilt 6. Kaika Laine oma sünnipäeval telemehe Vahur Kersna käevangus. Foto erakogust.

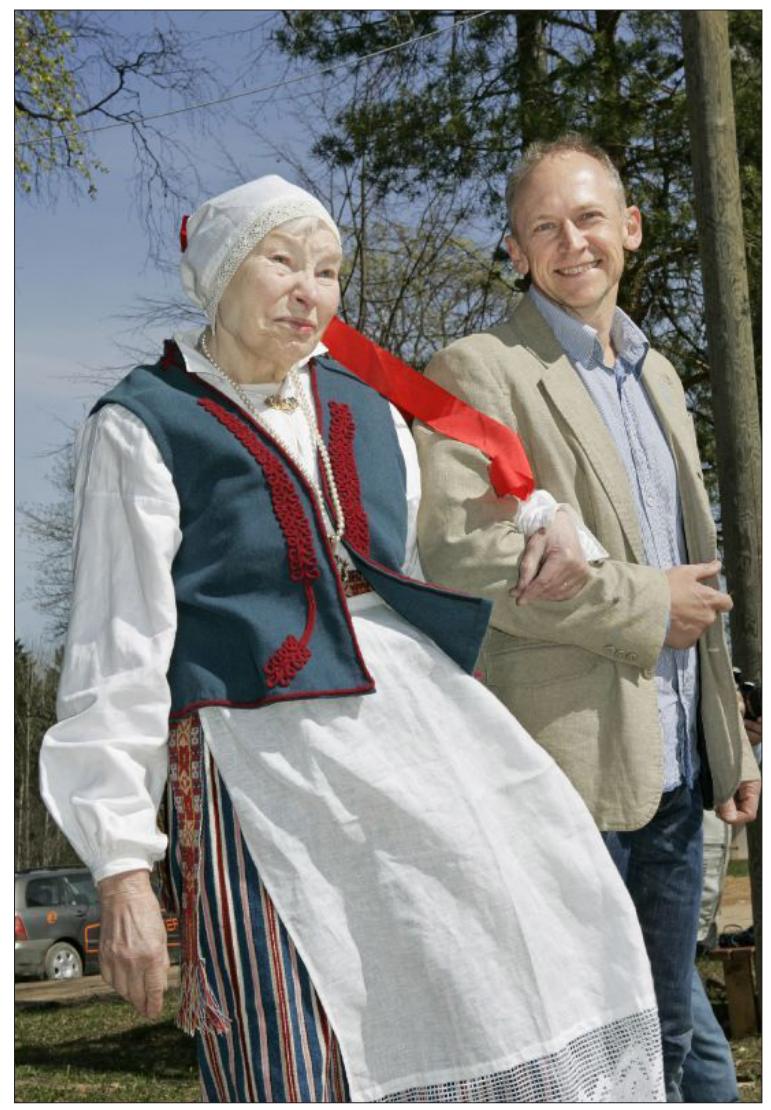

\section{Haigused, millega saadeti rahvaarsti juurde}

Registreerimisraamatute, arhiivis leiduvate saatekirjade ja intervjuude põhjal ulatuvad rahvaarsti vastuvõtule pöördujate diagnoosid kergetest tõsiste ja ülitõsiste haigusteni. ${ }^{18}$ Paratamatult pöördub osa isikuid ka hoopis teistsuguste, isikliku elu valikutega seotud küsimustega. Diagnooside rohkuse põhjal võib sedastada, et Kaika Laine raviseansse peeti efektiivseks paljude haiguste vastu, ja temasse usuti kui imearsti, kes suudab abi pakkuda ka lootusetus olukorras. Nimelt oli saabujate hulgas ravitavate haigustega patsiente, aga ka neid, keda toonane ega tänane meditsiin ei oska aidata. Tema juurde tuldi konsulteerima enne kirurgilist sekkumist, samuti diagnooside puhul, mis ei andnud paranemislootust, progresseeruvate haigustega, mille peatamiseks puuduvad tänaseni ravimid. 
[---] Tartust arsti juurest tulin, siis tulin kohe Laine juurde. Tema rääkis, mis mul viga on. Ja siis haiglast olin käimas, siis läksin jälle tema juurde. Ta aitas kaasa. Tema pani mul osa verd kapslisse, pool oli kapseldunud, see mind aitas. [---] (EFA I 9, 251/2 (6) < Urvaste khk, Antsla v, Lusti k Mare Kõiva (1996).)

Laine ongi mu päästnud, muidu mind polekski enam. Mehe surma järel käisin ma temalt abi saamas ja tema aitas mind, kui mul oli tervisega suur mure. Ma käisin abi saamas ja tänu temale mul jäigi opile minemata, siiani ma pole sinna läinud. Tegin tema õpetuse järgi ja olen siiani terve olnud. Ma olin mehe surma järel väga mures, võibolla ma ilma Laineta ei olekski enam töövõimeline. (EFA I 9, 254 (3) < Rõuge khk, Antsla v, Roosiku k - Mare Kõiva (1996).)

Rahvaarsti vastuvõtutoas on harilikult vähe tavaliste haigustega saabujaid ja suur on krooniliste, lootusetute ja raskete haigustega pöördujate osakaal. See muudab ravija töö keerukaks, nagu ka erinevate diagnooside ja haiguste rohkus.

Naastes 1980. aastate juurde, mil kahe süsteemi - riiklik ametlik meditsiin ja rahvameditsiin - vahel ei olnud leppeid, mille kohaselt oleks ametlikult saanud saata ühest süsteemist teise ravile või konsultatsioonile. Leebemat taimravi jm võimalusi kasutavaid või idameditsiinist huvitatud arste polnud tollal palju, eeldatavasti osa neist kuulus saatekirja andjate hulka. Eespool viitasin, et saatekirja patsiendile andmine tähendas riskimist litsentsi, töökoha ja pikaaegse haridusteega saavutatud positsiooniga. Niisiis eeldas saatekirja kirjutamine vastastikust usaldust, uskumist ja lugupidamist teise osapoole suhtes.

Laine Rohu nimelises arhiiviköites on aastatest 1986-1991 säilinud 242 saatekirja. Aastate lõikes jagunevad need järgmiselt: 1986 - 21, 1987 - 55, $1988-40,1989-63,1990-25,1991-11$, aastaarv loetamatu või puudub - 27 . Saatekirjade tagasihoidlik arv osutab, et selliseid patsiente oli siiski vähem kui saatekirjata saabujaid. Lõplikku vastuvõetud külastajate arvu ega proportsioone ei saa aga määratleda, sest Laine Roht võttis tollal vastu abiliseta. Vastuvõtt ja ravirituaal jagunes mitme ruumi vahel, ravija oli pikka aega teistes tubades, patsiendid omapead ja nii sujus registreerimine ja ravimise kirjalik osa omapäi. Küll annavad saatekirjad täpsema sissevaate, milliste haigustega saadeti konsultatsioonile või loodeti abi rahvaarstilt, kelle peamine vahend oli kaasavõtud ainete loitsimine.

Vaadates selle perioodi saatekirjaga saabunud patsientide diagnoose (neis on haigus määratletud enamasti üsna täpselt) saame sedastada kümneid erinevaid diagnoose. Eenduvad mitmed suuremad haiguste rühmad, nagu reumaatilised probleemid, erinevad kasvajad, allergiad, kuid ka psühholoogilised vaevused 
(sh depressioon). Registreerimisraamatud ja intervjuud toovad saatekirjade kõrval esile patsientide enesediagnoosi ja laiendavad pöördumiste inimlikke põhjuseid: lisanduvad näiteks sotsiaalsed probleemid perekonnas ja suhted kolleegidega, armuküsimused, aga ka näiteks vananemine ja paljud muud kognitiivselt keerulised olukorrad. Registreerimisraamat on selles mõttes tänuväärne allikas:

Käisin Teie juures 6. veebruaril väga raskes hingelises seisundis. Tänu Teie abile võin ja saan jälle rahulikult elada (Roht 1: 299).

Haiguste raskusaste on saatekirja saajatel väga erinev, ulatudes ravimatutest või raskesti ravile alluvatest haigustest (tavaliselt arstitakse professionaali järelvalve all) kuni krooniliste terviseriketeni. Loetlegem üksnes mõned diagnoosid: sclerosis multiplex, epilepsia, ateroskleroos, diabeet, halvatus insuldi järel, kilpnäärme talitluse häired ja kasvajad, erinevate elundite kasvajad, tuberkuloos, lumbaago, ajuvereringe häired, tromboos, migreen, vererõhu ja lümfisõlmede probleemid, polüoartriit, seropositiivne osteoartroos, reumatoidartriit, puusaliigese põletik, radikuliit, allergiad, sh neurodermiit.

Saatekirju on antud kõigile haigusrühmadele, kõigi organite kontrollimiseks ja nende kahjustuste ravimiseks: südame-veresoonkonna haigused (ka südamelihase põletik), hingamisteede haigused kopsupõletikust astma ja bronhiidini; mao- ja soolestikuhaigused ning muude siseorganite kahjustused kergematest raskemateni (hemorroidid, maotalitlus, kõhunäärme põletikud, neerud, pankreatiit, maksahaigused, sapikivid), nina-kurgu-kõrvahaigused koos põsekoopa põletikuga, günekoloogilised näidustused kuni viljatuseni; psüühikahäired; suuõõne ja hammaste probleemid; silmad ja nägemishäired; kosmeetilised probleemid; rasvumine, buliimia ja anoreksia.

Valisin lähemaks vaatlemiseks aastad 1988 ja 1990, kuivõrd need pidanuks peegeldama rahvameditsiini osas mõnevõrra erineva suhtumisega aegu. 1988. aasta neljakümnest saatekirjast üks oli antud kuueaastasele lapsele, kellel oli mitmeid psüühikast sõltuvaid haigusi, ühel saatekirjal puudus nimi, ent tervelt kuusteist saatekirja olid antud meestele. Meestest umbkaudu pooled on saadetud konsultatsioonile ilma lähema määratluseta (seda sõltumata lähetavast arstist ja lähtepaigast, nt Roht 1: 117-120). Määratud diagnooside seas on kaelaradikuliit, nimmepiirkonna põletik, raskekujulised südamepuudulikkuse nähud ja rasvtõbi. Naistel on diagnoosid mõnevõrra mitmekesisemad, need on saatekirjal alati kirjas: erinevad nahahaigused, südamehaigused, gastriit, radikuliidi raskekujulised vormid, allergiad, sh jahutoodete ja leiva talumatus, ja mitmel ka klimakteeriumi-aegsed vaevused. Märkimisväärselt on tervelt kolm patsienti saadetud raske diagnoosiga ja on palutud L. Rohult abi uue raviskeemi juures - taimravi väljatöötamisel. 
Tänuraamatus on 1988. aasta sissekandeid kõigest seitseteist ja neist suurem enamik on tehtud saatekirjade-välisel perioodil ehk aastaringselt, pigem mittesuvisel perioodil. Kohaviit on kümnel sissekandel (Viljandi - 2, Urvaste -1 , Varstu - 1, Valga - 1, Kõpu - 1, Vastseliina - 1, Põlva - 1, Pühajärve - 1, Võru - 1), mis esindavad umbkaudu 34 ravima saabunut, neist 14 on mehed. Korduvalt külastajad on kolme kirjapaneku taga, ent konkreetset haigust mainitakse vaid paaris tekstis.

1990. aasta 25 saatekirjal (Roht 2) on diagnoosidena märgitud: sclerosis multiplex; kardiomüopaatia, kahel korral reuma, peavalu (ja nõrkus), kõrgvererõhu probleemid (kolmel patsiendil, kellest kahel kombineerub see liigesepõletikuga), radikuliit (kolmel patsiendil, ühel kombineerub diabeediga), osteokondroos (kaks diagnoosi), silmahaigustest glaukoom, kasvaja silmalaul, sapipõie põletik, kõhunäärme põletik, müoom, rinnavähk (kaks diagnoosi); ekseem, allergia; psühhiaatriline probleem, epilepsia, kogelemine, voodimärgamine. Üks patsient on tulnud eriarsti (kirurgi) konsultatsiooniks väljakirjutatud saatelehega.

1990. aasta kohta puudub registreerimisraamat, kuid on alles nn tänuraamat, mille abil saame mõningase ülevaate teistest vastuvõtule saabujatest. ${ }^{19}$ See kirjalik allikas on spetsiifiline: selles väljendavad oma tänu vastuvõtmise eest umbkaudu viiskümmend kolm külastajat, neist kaheksa on saabunud mitmendat korda kas oma tervisehädaga või toonud ravile mõne lähedase. Tänuraamat toob välja ka pikemat aega ravil olnud isikud.

Olen Teie juures ravil varsti juba neljandat kuud. Tervis on paranenud ja ma loodan peatset täielikku paranemist.

Andku Jumal ka Teile tervist, rõõmu ja rahu hingele!

3. märts 1990 Viive Võrust. (Roht 1: 295)

Käisin Teie juures 1984. a. radikuliidiga. Peale Teie rohtude tarvitamist ei ole mul enam mingisugust radikuliiti. Nüüd usun teie jõusse ja tulin koos lapsega. Loodan kindlasti saada siit abi.[---]

Peeter Viljandist. (Roht 1: 298)

Minu poeg, kelle Sa terveks ravisid seitse aastat tagasi, palus Sulle viia tervitusi ja Issanda Õnnistust. Nü̈̈d olen ise maohaavadega hädas. Loodan jällegi Sinult abi saada.

Tuhat tänu Sulle veel kord poja eest. [---] (Roht 1: 301)

Peale vähjaoperatsiooni kannatasin valudes (lümfiteedes olid takistused ja paisud). Siia majja tulin kü̈̈rus ja halades, kuid siit lahkusin juba tollel päeval normaalselt kõndides. (Roht 1: 305) 
Üllataval kombel esineb mõnikord traditsioonilisi diagnoose, mida ametlikud haigusloetelud ei sisalda, nagu kaetamine, st rahvapärase etioloogia kohaselt kurja silma või sõnaga teise inimese tervise kahjustamine. See on üllatav, sest kuulub loomulikuna rahvaarstide diagnooside hulka, kuid ei ole endastmõistetav arsti poolt aktsepteeritud etioloogiana. Sama kehtib ka needuse alla panemise / needuse all olemise kohta. Ilmselt on eriti viimane naasnud Eestis rahvapärasesse diagnostikasse sensitiivide ja New Age’i ravijate vahendusel. Samuti on saatekirjasid, kus arst pole osanud haigust diagnoosida, vaid on eeldanud rahvaarsti abi haiguse selgitamisel.

Saatekirjade ja registreerimisraamatute põhjal vaatles patsientide pöördumiste põhjuseid aastal 1989 õpilasuurija Janila Raudsepp, kelle tööd on vahendanud oma raamatus Reet Kudu. Toome siinkohal tema uurimuse põhitulemused: J. Raudla uurimuse põhjal olid sagedasemad pöördumispõhjused liigesehaigused, järgnevad südamehaigused, närvilisus ja valud. Haruldastena nimetab ta radikuliiti, suhkruhaigust, alkoholismi, nägemishäireid, põletikke ja unehäireid (Kudu 2009: 143 jj). Rahvaarstile suunatud haigete diagnoosid katavad laia haiguste ala, millele perearst oleks leidnud ja leiaks tänagi lahenduse koostöös eriarstide tugisüsteemiga: saadetutel on arvestatav hulk eriarstide pädevusse kuuluvaid haigusi, lisanduvad paranemislootuseta patsiendid. Võime üldistada, et raviarstil oli krooniliste ja lootusetute haigustega rahvaarsti juurde saatmine ainulaadne lisavõimalus põdeja abistamiseks. Miks mitte katsetada reuma, kulunud puusaliigese, radikuliidi, sclerosis multiplexi, depressiooni, psühhiaatriliste hädade, migreeni juures patsiendi mentaalsuse ja hingejõu ning ime kaasamist?

Saatekirja pole võetud kergemate igapäevaste haigustega, nt juba nimetatud külmetushaigused, samuti suurem osa traumasid, mis vajavad kiiret abi. Siiski ka rasketest haigustest kõikidega rahvaarsti juurde ei pöördutud, näiteks raskete neerukahjustustega mitte, küll aga neerukividega; välistatud on ülirasked liikumispuuded, kuid liikumisraskused on olnud näidustatud saatmispõhjus. Kaasasündinud geeniriketega seotud haigused saatekirjadest ei ilmne, neid L. Roht oma sõnutsi ka vastu võtta ei soovinud. Küll aga on teekond rahvaarsti juurde võetud ette kriisisituatsioonis, nagu kasvaja diagnoosimise järel või enne operatsioone, kui inimesed on valmis radikaalseteks eluviiside muutusteks tervise ja elu nimel või otsivad alternatiivseid võimalusi enda päästmiseks.

Huviväärne on saatekirjade vormistus. Enamik arste on täitnud saatekirja blanketi tavapäraselt: patsiendi nimi ja vanus, ladinakeelne diagnoos ja muu asjakohane informatsioon, nt määratud ravimid. Osa arste on siiski kasutanud blanketi tühja tagakülge, saatekiri võib olla kirjutatud vabas vormis koos eestikeelse diagnoosiga, mis viitab teatavale reservatsioonile toimuva suhtes (või lihtsalt ettevaatusele). Sageli pole märgitud, kelle juurde suunatakse või 
on üldsõnaliselt kirjas "rahvaarsti juurde konsultatsioonile", aga ka "L. Roht. Konsultatsioonile". Arstid on andnud patsientidele kaasa röntgeniülesvõtteid, EKG-filme, vere- ja uuriniproovide vastuseid - otsekui saates oma patsiendi eriarsti vastuvõtule. Ka viitab osade saatekirjade tagaküljele kirja pandud analüüsitulemuste esitamine tüüpiliste professionaalsete lühenditega, eelnevate või viimaste ravimite loetlemine, et rahvaarsti teadmisi peeti võrdväärseteks.

Samas leidub saatekirjasid, mis on patsiendile antud hoopis eriarsti vastuvõtu jaoks, sh hinnatud spetsialistide juurde, kelle vastuvõtule pääsemiseks tuli oodata kuude kaupa. Saame üksnes oletada põhjuseid, miks valiti selle asemel käik rahvaarsti juurde. Kindlasti oli peapõhjus usaldus rahvaarsti vastu, välistatud pole pettumine ametliku süsteemi võimalustes, kartus radikaalsete operatsioonide ees ja isiklikud valikud oma raviskeemi suhtes, mis lubasid eelistada tundmatut, kuid uusi lootusi andvat arstimisviisi.

Kokkuvõttes on saatekirjade tunnus, et nad on sesoonsed, st neid on välja antud ennekõike perioodil juunist augustini, samas muud allikad osutavad pidevale patsientide saabumisele. ${ }^{20}$

\section{Saatekirja andjad ja patsiendid}

Kaika Laine tuntus kasvas aastatega ja tema juurde sõideti 1980. aastate lõpul kõikjalt Lõuna-Eestist, nagu osutavad saatekirjadki. Iga aastaga enam sõitis kohale patsiente kogu mandri-Eesti linnadest ja laiemaltki. See oli ühtlasi omapärane periood, millal rahvaarstid aktiivselt omavahel suhtlesid ja üksteist külastasid sihiga tutvuda, võrrelda meetodeid, õppida üksteise juures või lahutada meelt (Kõiva 1995, 1996). Mõnevõrra toimivad seesugused võrgustikud tänaseni.

Aastate lõikes erinevad saatekirja saamise kohad, seda näitavad selgesti kahe aasta võrdlused ja mis osutab asjaolule, et esmamäärav oli siinjuures patsientide nõudlus, arstide omatahtsi suunamine jäi ilmselt tagasihoidlikumaks.

1988. aastal on saadud saatekirju Tartu Polikliinikust (1), Rõugest (1), Jämejalast (2), Abjast (5), Kõpust (2), Viljandist (13), Valgast (6), Tuhalaanest (1), Raplast (2), viie arsti saatekirjalt pole kohaandmed loetavad.

1990. aastal on saadud saatekirjad Tartu Polikliinikust (3), Sangastest (5), Kõrvekülast (2), Moostest (1), Pukast (1), Tõrvast (1), Valga Keskhaiglast (2), Võrust (1), Leevilt (1), Türilt (5), 4 arsti saatekirjalt pole kohaandmed loetavad.

1990. aasta patsientide geograafia on tänuraamatu põhjal laiem, ehkki suure osa moodustavad Kaika küla lähema ümbruse ja Lõuna-Eesti paikadest pärit sissekanded: Lüllemäe (2), Antsla (1), Tsooru (1), Valga (1), Kuldre (2), Mooste (2), Rõuge (1), Võru (1), Põlva (1), Kanepi (1). Teistest suurematest paikadest 
moodustab olulise keskuse Tartu (6) ja lähialad Nõo (1) ja Elva (1) ning muu Eesti, kust Kaikale sõitmine oli keerukam: Puurmani (1), Viljandi (1), Hiiumaa (1). Pealinn Tallinn (4) on Tartu ja Lõuna-Eesti piirkonna kõrval oluline paik, kust patsiendid saabusid. Tervelt 11 juhul ehk umbkaudu viiendikul juhtudest on kirjutaja esitanud oma nime ja kuupäeva, ent jätnud märkimata päritolukoha.

Saatekirjade periood toob esile institutsioonid ja arstid, kes olid valmis haiget rahvaarsti juurde saatma: neid kirjutasid nii eriarstid kui üldarstid. Saatekirjasid on kirjutanud välja umbes 40 meedikut. Haigeid on saadetud Lõuna-Eesti suurematest linnadest: Tartu, Võru, Viljandi, Võhma, Valga, samuti Tartumaa, Võrumaa ja Viljandimaa väikehaiglatest, arstipunktidest, velskri-ämmaemandapunktidest. Lisaks leiame saatekirju Lääne-Eesti suuremast linnast Haapsalust, Põhja-Eesti tööstuspiirkonda jäävast Kohtla-Järve linnast, Paidest, Jänedalt ja Tallinnast. Tihedam koostöövalmis arstide võrgustik paiknes siiski laiemas mõttes Lõuna-Eesti alal, mujal töötavad arstid on olnud pigem erand. Mõnikord on saatekirja küsitud erinevatele pereliikmetele ja need on vormistatud eraldi lehtedena. Vahemaid arvestades tundub selline praktika (ühiselt sõita) kõigiti mõistlik. Saatekirju vaadates tundub, et pöördujate seas on aktiivsem vanuserühm 40-60, kuid leidub ka 30aastaseid, samuti vanemaid. Lapspatsiendid pole eriti sagedased, see ilmnes ka kahe valikaasta ainestikust. Haiget võib olla (ilmselt tema palvel) korduvalt saadetud Kaika Laine juurde, mis annab põhjuse arvata, et neil arstidel oli sümpaatia rahvameditsiini ja alternatiivsete raviskeemide vastu. Vähemalt üks arstidest töötab tänasel päeval Waldorf-meditsiini meetodeid kasutades. ${ }^{21}$

Kindlasti oleks huvitav arstide sooaspekt, nais- ja meesarstide vahekord, kuid see jääb selgusetuks: arstid on kirjutanud enamasti üksnes allkirja, vaid osa on kinnitanud seda isikliku nimelise pitsatiga. Psüühilistest nähtustest huvitatute soolise ja arstiameti pidajate üldstatistika põhjal võime eeldada, et naisarste oli rohkem.

\section{Patsientide enesediagnoosid ja ravimisrituaali kirjalikud osad}

Patsientide narratiive ja enesediagnoose esindab suuline või kirjalik lühiversioon: lühiandmed, mille nad ise või keegi rahvaarsti abiline kirjutas vastuvõturaamatusse või tänuraamatusse ja lühike suuline kommunikatsioon vastuvõtu ajal. Kogu ravimisrituaali kirjalik jälg sarnaneb lühiduselt ametlike arstide kokkuvõttele haigusloost, kuid on veidi teisiti organiseeritud. Tuginedes oma isiklikele osalusvaatlustele ja teiste uurijate kirjeldustele, iseloomustan lühi- 
dalt Kaika Laine ravimisrituaali, mis aastate jooksul varieerudes, säilitades üldjoontes sama struktuuri. Palusin tavaliselt võimalust viibida patsientide vastuvõtmise ajal ruumis, et teha märkmeid või lindistada, harvem filmida. Harilikult lahkusin Laine Rohu kannul rohu valmistamise ruumi, kus jälgisin tema tegevust, hiljem naasin tema kannul rohu üleandmise ja õpetuste ajal. Seega on mu vaatlustes teatavad ajalised tühikud.

Abi järele pöördunud patsient/patsiendid võeti vastu ikoonide, piltide ja lilledega kaunistatud spetsiaalses eesruumis - vastuvõtutoas. Ruumis paiknes laud toolidega patsientide jaoks. Seal tervitas saabujaid rahvaarst ja seal ta ka suhtles nendega. Järgmisena laskis ta neil märkida oma loo ja tulekupõhjuse lühidalt vastuvõturaamatusse (või tegi seda abiline). Sõltuvalt patsientide arvust oli vestlus üldisem või isiklikum. Kui raamatusse kandis kokkuvõtte abiline, oli patsientidel oma muredest rääkimiseks rohkem aega.

Patsientide muredele loodi sobiv sissejuhatus, meenutades ühiseid tuttavaid jm viisil. Korjanud patsientidelt kaasatoodud ravimitoorikud (vesi, mesi, sool jm ained), suundus ta neid loitsima naabertuppa, umbkaudu ruumiossa, kus ta ise oli sündinud ja kus paiknes nüüd sahtlitega laud. Tagasi patsientide juurde pöördus ta harilikult poole tunni või tunni aja pärast, andes üle nimelise ravimi, järgnesid kõikidele mõeldud, ühesugune suuline ravimi kasutamise juhend, lühem suhtlemine ja hüvastijätt.

Mille poolest erinevad patsientide räägitud ja kirjutatud lood nendest, mis on kirjas saatekirjal? Saatekirjal on lühidiagnoos või probleem, vastuvõturaamatus aga üksteisele järgnenud haiguste loetelu, inimese esitatud haigestumise ajalugu, vahel ka haigestumise põhjuslikkus ja patsiendi sotsiaalset olustikku puudutavad andmed. Vastuvõturaamatusse kirjutati kõik omakäeliselt: aadress, nimi, vanus, diagnoos ja haiguslugu. Enamasti meenutab kirjutis ametliku meediku koostatud haiguslugu, mille arst paneb kirja patsiendi jutu põhjal, kuid võib esineda ka suuri kõrvalepõikeid. Järgnevalt näitena kaks omakäelist haiguslugu köitest Roht 4:

2. juuni 1988 .

Otepää, [nimi, meespatsient], 50 a.

Paremas jalas esineb ägedakujuline närvipõletik. 1967. a. märtsis oli tuuletõmbus selgroo keskkohast, millest tekkisid üldised tervisehäired, paremal pool allpool rindkeret külje sees teravad suruvad valud. Kõhus esinevad ka valud, on nagu valus tükk üleval pool rinda.

Ka naaber, kes on minu vastu väga õel, mõjutab tugevasti minu tervist. Nõiub ja needib mind kuradist. Ähvardab mind surmaga vastu hakkamise puhul. 
Mehega on kaasas naine, kes kinnitab napisõnaliselt probleemi olemust - ema on naabri käitumisest haige.

\section{3. juuni 1988}

Viljandi rajoon, Olustvere

[Nimi, mees], 31 a.

Koolis käies II klassis algasid ägedad peavalud. Võeti selgrooüdi proov, arvati peapõletikku, kuid proovid seda ei näidanud, ka selgrooüdi proovi võtmise tagajärjel on seljas selle koha peal valud.

Vastuvõturaamatud, mida on kahjuks säilinud vaid mõne aasta kohta, annavad minu meelest üsna ausa ülevaate isikutest, kes käisid Kaika nõia vastuvõtul, missugused olid probleemid, mida oli ette võetud haiguse vastu ja missugused olid inimese isiklikud seletused olukorra kohta.

Vahel on arstid kirjutanud L. Rohule haigusest kokkuvõte saatekirja tagaküljele, mis taas meenutab ametivennale mõeldud teksti:

$P$ [a] $t$ [siendi]l liigesevaevused 2-3 aastat. Raviks saanud Bentaltasoni 1 tablett 4 korda päevas, südame raviks Celamoli 1 tabl $x 2$.

$P[a] t$ [siendi]l tegemist hulgiliigestepõletikuga. Peamiselt haaratud parem hüppeliiges. Elektriravi saanud ei ole. Teinud mähiseid Wisnevski salviga. Palun konsulteerida ravi ja diagnoosi osas. (Roht 1: 107)

Kui haiguste kirjeldused rahvaarsti registreerimisraamatus on detailirikkamad, esile tuleb rohkem tervisehäireid, räägitakse haiguste taustast ja esitatakse põhjuseid, siis saatekirjal on võrreldes vastuvõturaamatuga palju vähem informatsiooni, sest suunamine on seotud kindla haigusega (haiguste rühmaga). Ka vastuvõtu-protsessi suulises loos esitatakse detaile, tuuakse mõnikord esile hoopis teisi haigusi kui on kirjas. Saatekiri, vastuvõturaamatusse kirjutatu ja tänuraamatu sissekanne moodustavad ideaalsel juhul kokku kirjaliku haigusnarratiivi, mis sisaldab olulist informatsiooni rahvatervishoiu ja haiguskujutelmade kohta.

Külalis- või tänuraamat anti patsiendile ooteruumis, seda sai lugeda rohu valmimise ajal vaikselt omaette või valjusti üksteisele. Sõnumite ja kirjade lugemine süvendas teraapilist efekti, toimis lugemisteraapiana, kuna enamik kirjapanekuist on seal edulood ja sisendavad ootajatesse optimismi, et kõige halvemagi prognoosiga haigusest on võimalik terveneda. Tänuraamatu sissekanded osutavad, et Kaika Laine juures käidi korduvvisiitidel, tagasi tuldi vahel aastate pärast. Tänuraamatu tekst on iseloomult erinev, st seal ei anta enamasti täpset informatsiooni kõikide haiguste kohta, vaid tuuakse esile paranemise protsess või lootused paraneda. Samuti on selle eesmärgiks ennekõike täna- 
da vastuvõtu eest ja edastada omapoolsed head soovid ja õnnistused ravijale. Täiesti ilmselgelt on seda täitnud osa külastajatest.

\section{Kallis Laine!}

Sinu võimete suurus tuleb selgelt esile raske haige (selgroo tuuleroos) juures, kelle Sa päästsid kõige halvemast. Kõik Sinu ennustused tema käima hakkamise kohta on täide läinud. Ta on jälle muutunud inimeseks ja toredaks perekonna toeks. Loodame, et selle külaskäigu järel paraneb ta veelgi.

Ka meie teised perekonnaliikmed oleme oma tõbedele abi saanud.

Annaks jumal, et sa suudaksid. (Roht 3: 253)

Tänuraamat teenib arstimisrituaalis ka rahvaarsti usaldusväärsust ja autoriteeti suurendava faktorina (vt New Age'i ravijate puhul Altnurme \& Lyra 2004). Ent ikkagi tasub meeles pidada, et nagu muutus kümnendite jooksul arstija ja tema sotsiaalne staatus kogukonnas ja laiemalt rahvuskultuuris, nii on muutunud ka tekstid, mida kirjutati tänuraamatutesse, samas kui registreerimisraamatute enesenarratiivid on ehk püsivaima struktuuri ja sisuga. See kõik vajab edasise formaliseerimisprotsessi käigus lähemat analüüsimist.

\section{Diskussioon ja kokkuvõtteid}

1980. aastatel pääsesid valitud rahvaarstid meediasse, esmalt folkloristide ja teiste nendega kokkupuutunud isikute vahendusel, hiljem prevaleerisid professionaalsete ajakirjanike kirjutised. Avaldati intervjuusid, neilt küsiti eksperthinnanguid ja tutvustati nende maailmavaadet, samuti ravimisviise. Meediauudised hõlbustasid teabe levikut, sest üksnes suulise informatsiooni korral poleks sõnum saanud nii laialdast kandepinda. Samuti on meedia, eriti konkreetsete ajakirjanike järjekindel tähelepanu kujundanud mitmele meediumile/arstijale väärika staatuse ning hoidnud nad kogukonna mäletamise ja tänu keskmes, loonud rahvuslikele kangelastele lähedase imago.

Kahtlemata oli ametliku meditsiinisüsteemi esindajate käitumine julge, sest nendel oli kaotada pikkade õpinguaastate ja praktiseerimisega saavutatud arstilitsents. Võibolla on see põhjus, miks osa saatekirja andjatest vormistas selle tavalisest erinevalt. Saatekirjaga rahvaarsti juurde lähetamine kaotas kiiresti aktuaalsuse ja hakkas vähenema sotsiaalpoliitiliste olude muutudes juba 1990. aastate alguses on arstide kirjad lakanud. See viitab rahvaarstide adapteerumisele uue aja tingimustega. Karmistunud reeglid kriitilisel perioodil pani neid otsima legitiimsust, mille hulka liigitub ka saatekirja nõue. Seesama 
adapteerumisprotsess lubas nõudest loobuda uutes ühiskondlikes oludes. Vaatlusalusel perioodil kombineerusid limiteeritud juurdepääs ametlikule kvaliteetsele meditsiiniteenusele ja ametliku meditsiini vaenulikkus rahvapärase ravi vastu ning patsientide vajadus alternatiivse ekspertiisi ja arstimisvõimaluste järele. Konflikt kogukonnas ja võimudega sundisid rahvaarste vastukäiguna paluma patsientidelt arsti saatekirja, et tõestada oma koostööd. Samas kogukonna silmis tõstis rahvaarstide ja ametliku meditsiinisüsteemi väidetav koostöö usku ja positiivset suhtumist rahvaarstidesse. Selle kõigega kaasnes terve müriaad erinevaid põhjuseid, miks 20. sajandi teisel poolel valiti kaugel elav kuulus ravija ametliku meditsiini esindaja asemel.

Tegelik koostöö, st ühine diagnoosi ja ravi määramine, ravimistulemuste analüüs, siiski ei toiminud. Küll aga delegeeriti saatekirjaga teatud haiguste ravimine vastavalt patsiendi soovile ja valikule rahvaarsti kätesse. Polnud mõeldav minna ametliku arsti või isegi psühhoterapeudi juurde küsima, kas abielumehel on sinuga midagi tõsisemat plaanis või kas kirglikust armastusloost areneb midagi turvalist, vähemalt igapäevane kooselu. Kas tige ülemus taltub või on targem otsida uus töökoht? Mida teha ja kuidas saada hakkama lootusetu diagnoosiga lähisugulasega? Kas lootusetule diagnoosile pole tõesti ühtegi ravimit? Kas laps on kõva peaga, jonnakas või hoopis haige? Kas ebamäärased valud südames tulevad närvidest või on tõsise tervisehäire signaalid? On selge, et mitmele neist ja kümnetele teistele küsimustele suudaks vastata kogenud psühholoog või psühhoterapeut, samuti eriarstid. Samas sai selgeltnägija võimetega ravijalt kiirema ja ammendavama vastuse, sealjuures lisatingimusteta, nõueteta reformida oma eluviisi.

Tuleb märkida, et psühholoogide ja nõustajate süsteem oli 1980. aastate alguses arenemas, kuid neid ei töötanud väiksemates asulates. Samuti takistasid psühholoogi konsultatsioonile pöördumist eelarvamused - seda häbeneti. Keeruliste elu- ja terviseprobleemide puhul võis inimene jääda üksinda või sattuda vastasseisu oma lähedaste ja kolleegidega - niisiis oli tarvis usaldusväärset eksperthinnangut või ärakuulajat, kelleks sobis rahvaarst.

On märkimisväärne, kuivõrd keerulistest haigustest vabanemine delegeeriti sümboolsele ravile - verbaalselt mõjutatud lihtsatele ainetele - ja kui paljud patsiendid said sellest abi või vähemalt leevendust. Kirjalike allikate vaatlemine osutab, et sageli saabusid inimesed ametlikust diagnoosist erinevate muredega, neil oli haiguste kõrval muid raskusi, nt sotsiaalsed, kultuurilised ja psühholoogilised probleemid, mis ajendasid rahvaarstilt abi otsima.

Tänaseks on palju rohkem teavet pärilike ja parandamatute haiguste kohta, nagu langetõbi, teatud kae liigid, astma, diabeet ja halvatus. Neile on leitud leevendavaid medikamente ja abistavaid instrumente, mida eelmisel sajandil veel polnud, mistõttu tuli leida alternatiivseid lahendusi ning imearstid ja 
rahvameditsiin oli üks võimalus. Samas ei kao lahendamatud haiguslood ega probleemid inimeste elust kunagi, mistõttu püsib aktuaalsena vajadus abi ja alternatiivsete lähenemiste järele.

Kaika Laine juures jäi suurem osa ravimi valmistamisest, sellega seotud verbaalsest ja maagilisest praktikast patsiendi kogemis- ja tajumisulatusest välja, patsiendi toodud tavalistest ainetest valmis imeravim. Ka ravimi valmistamise paigad jäid patsientide eest müstiliseks pühaduse ja imedega seotud alaks, saladuseks. Midagi kogu protsessist oli teada meedia vahendusel, ent see oli suuremas osas siiski ligipääsmatu ala, kus algasid teistsugused võimalused. Toonaste salvestuste põhjal on selge, toimemehhanisme ei osanud patsiendid seletada, kuid opereeriti mõistetega maagia, uskumine, hinnati isiksuse fluidumit ja Kaika Laine isiklikke võimeid. Kogu ravimisrituaal ja selle toimemehhanismid olid uskumise ja usupõhised.

Kaika Laine teadmised olid seotud pere- ja kohaliku pärimusega, seos üleloomulikkusega, toetumine kiriku autoriteedile ja samas tema isiklik toetus kirikule. Ta kandis edasi 19. ja 20. sajandi rahvapärase arstimise tüüpilisi võtteid, tema teadmised olid sümbioosis erinevat liiki trükisõnaga, mida ta sulandas oma teadmiste ja kasutuspraktikaga. Kirjutamine, käsikirjad, lugemine olid tema raviriituse lahutamatu osa, autoriteetne patsiendi mõjutamise vahend ja ühtlasi rituaali tugi. Tervenemiseks on vaja lisaks uskumisele, usaldamisele ja ootustele ka edulugusid ja autoriteeti sisendavat suhtlemist. Selle loomisel abistasid ravialuseid kirjalikud tervenemis- ja tänujutud.

\section{Kommentaarid}

1 Artikkel on valminud IUT 22-5 raames.

${ }^{2}$ Väikese valiku nõukogude perioodi legendaarse ravija ja meediaisiku Džuna Davitašvili elukäigust ja nimekatest patsientidest leiab näiteks aadressidelt https://ru.wikipedia. org/wiki/Джуна; http://zivot.cas.sk/clanok/20657/liecitelka-kremelskych-vladcovdzuna-davitasvili-sama-nechapala-aka-energia-vychadza-z-jej-ruk (Život 2015); http:// www.la.lv/noslepumiem-apvita-legenda-dziedniece-un-parege-dzuna-kas-vina-bija/ (Prūse 2015); eesti keeles vt Tael (http://www.ohtuleht.ee/681009/venemaa-leinabbreznevi-imeravitsejat-dzunat).

3 Davitašvili võimeid tutvustas 16. augustil 1980. aastal ajalehes Komsomolskaja Prav$d a$ Lev Koroljov (Wikipedia andmed); ilmselt mugandas eesti meedia venekeelseid meediatekste. Eesti imearstidest on Vigala Sass osutanud silmast silma kohtumisele kuulsa ravijaga (intervjuud eraarhiivis).

4 Davitašvili arhiiv sisaldab fotosid ja videojäädvustusi kohtumistest poliitikutega, sh talle mentorina Moskvas teed sillutanud Gruusia pikaaegse riigijuhi Śevardnadzega, ka mitmete eesti ravijate kohta on teada eesti poliitikute visiidid (nt Vigala Sassi registreerimisraamatud 1980. aastatest, tema intervjuud) ja nende sõna kontaktide kohta kõrgete riigitegelastega. Sovetiaegsete arstimisstrateegiate seos fiktsionaalsete 
ja mittefiktsionaalsete narratiividega vajab siiski edasist täpsustamist. Ka näiteks Kaika Laine on väitnud, et teda kutsuti N Liidu riigipead Leonid Brežnevit ravima, aga Brežnev suri enne ära (nt Jürgen 2012: 299).

5 Teadaolevalt sattus kaebuse peale kohtusse ja vangistusse näiteks Anton Taits (Kõivupuu 2004).

6 Tegemist on pikema uurimisteemaga, seetõttu on piirdutud mõne esialgse näitega.

7 Lainet külastasid läbi aegade lisaks patsientidele intellektuaalid, teised ravijad, ka inimesed, kellel oli soov vestelda ja kohtuda eriliste võimetega isikuga. Teatava läbilõike erineva motivatsiooniga saabunud külalistest, kes kas üksinda, koos sõbra või patsientidega külastasid Kaika nõida, saame Einar Ellermaa ja Inge Pitsneri 2013 avaldatud raamatu vahendusel. Sealt tõusevad esile pikaaegsed suhted mitmete rahvaarstidega, mitme arstiga, kes on tuntud alternatiivmeditsiini pooldajatega.

8 Teadmiste vahetamise kõrval toetas seda vajadus anda teadmised edasi. 2002. aastal üldistab Pulga Jaan: "Ta nagu vanem inimene ja... Nagu püüdnud teistele üle anda, aga see alati ei ole niimoodi - see üleandmine.” (Intervjuu 2002).

9 Kaika Laine seostas 33. eluaastat Jeesuse vanusega. Ühes intervjuudest täpsustab ta muid tingimusi: [---] Laine saatis nad välja ja tagasi tulles rääkis ta, et on oma ravimisvõime saanud 33. eluaastal: "Enne oli tunne, et saad selle võime ja siis see võime alles tuleb.” [---] (RKM II 454, 419/98 < Karula khk, Kaika k < Urvaste khk - Rain Mikser, Agne Sisask, Karin Tamm, Tõnu Tender (1992).).

10 Teave selle kohta, missuguseid aineid on tarvis kaasa võtta, kuidas käituda, registreeruda, kuhu sõita ja palju muud levis suuliselt külastajalt külastajale, kuid 1990. aastate intervjuudes ja meedia vahendatud pöördumistes loetleb ta juba ise alati soovitavad ained, mis kaasa võtta.

${ }^{11}$ Intervjuudes esitab ta erinevaid andmeid. Ka inimeste mälestused laiendavad L. Rohu poolt kasutatud kirjalike ja trükiallikate loetelu. Ümberkirjutusi on teinud tema jaoks ka teised isikud ja üsna tüüpiliselt 1980. aastatel aktiivselt tegutsenud rahvaarstidele on ta oma käsikirju jaganud lahkelt ka teistega (Kõiva 1995). Ühe intervjuu ajal näitas ta oma loitsude allikana ilma kaanteta Eesti rahvalaulude III köidet (toimetanud Ülo Tedre), samuti Kadi Aabilt saadud raamatut Õndsaks tegev Ketsemane aed, Evangeliluterluse usuliste igapäevane palve-raamat (Tln 1890); eesti-ja saksakeelset Gesangbuchi, mis sisaldab nt lk 329 epilepsia ja krampide vastaseid sõnu, lk 491 astma ja lk 528 põrutuse vastaseid sõnu ning J. Kõpu Väikest palveraamatut, mis on trükitud Eesti Vaimuliku Raamatu poolt Stockholmis aastal 1984.

${ }^{12}$ Autor sõitis BBC võttegrupiga kaasa kui intervjueerija ja teejuht. Märkigem, et suurem osa erinevatele saatejuhtidele, intervjueerijatele ja külalistele jutustatud elulooga seotud andmeid, sündmusi ja neist vormitud narratiive olid stereotüüpsed ja kuulusid püsijuttude / keskse repertuaari hulka.

${ }^{13}$ L. Roht tõmbus ravipraksisest korduvalt tagasi, sagedasti tervislikel põhjustel.

${ }^{14}$ Maria Treben (27.09.1907, Žatec, Böömimaa - 26.07.1991, Grieskirchen, Austria) sai 1980. aastatel tuntuks oma raviraamatutega, mille isetegevuslikud tõlked ja masinkirjakoopiad levisid ka Eestis.

${ }^{15}$ Vt lähemalt Pärn 2012, kes toob välja mh iseloomulikke motiive.

${ }^{16}$ Vähemalt üks eluloost rääkiv raamat on teadaolevalt veel kirjutamisel.

${ }^{17}$ Kogukonnale olulistele isikutele nimeliste pinkide rajamise algatas Vahur Kersna 21. sajandi esimesel kümnendil ja see põhjustas mitmeid vastakaid seisukohti. Vastav 
traditsioon Eestis puudus, pigem oli tegemist meedia kaudu tuttava nähtusega, mis kanti isikliku algatusena üle Eesti kultuuriruumi. Vaidlusi tekitas ka küsimus, kes määrab pingisaaja ja kust peaks tulema selleks rahastus. Juurdunud traditsiooniga riikides (nt Bulgaaria, Austraalia) annetasid sellisteks ettevõtmisteks raha seltsid või üksikisikud; Eestis kohalikud valitsus- ja kultuuriorganisatsioonid, aga ka kohalikud inimesed. Tänaseks on sääraseid pinke rajatud erinevatesse Eesti paikadesse, väärtustades kultuuritegelasi, keeleteadlasi, popkultuuri massimaitse esindajaid (estraadimuusika viljelejad, külapidude muusika autorid jt), aga ka kultuuri seni avalikkuse eest varjul olnud külgi.

18 Täpsem statistika saatekirjade kohta on autori valduses.

${ }^{19}$ Diagnoosi ja saatekirja väljastamiskoha abil püüdsin eristada saatekirjaga saabujaid ja muid patsiente. Kuna tänuraamatusse tihti haigust ei märgita, siis oli kohal küllaltki oluline roll.

${ }^{20}$ Lähemalt autori valduses olevas analüüsis.

${ }^{21}$ Ehkki mitmete arstide nimed ja isikud on tuvastatavad, on siinjuures isikuandmete esitamisest loobutud eetilistel põhjustel, nagu pole esitatud ka patsientide nimesid, mis on saatekirjadel selgesti kirjas.

\section{Allikad}

EFA -Eesti folklooriarhiivi rahvaluulekogu, Eesti Rahvaluule Arhiivi kogu, peamiselt materjalid alates $1996 \mathrm{jj}$.

RKM - Eesti TA Fr. R. Kreutzwaldi nim. (Riikliku) Kirjandusmuuseumi (nüüd Eesti Kirjandusmuuseumi) rahvaluule osakonna rahvaluulekogu, peamiselt 1945-1996.

Roht 1, Roht 2, Roht 3, Roht 4 - 1990. aastatel L. Rohu kodusest arhiivist Eesti Rahvaluule Arhiivi hoiule toodud materjalid.

Intervjuud 1990, 1992, 2002 - folkloristika osakonna digitaalne arhiiv, intervjuud L. Rohuga, sh patsientide vastuvõtud perioodil 1980-2006.

Vigala Sassi intervjuud folkloristika osakonna digitaalses arhiivis (1980-2006) ja Vigala Sassi nimelises kogus Eesti Rahvaluule Arhiivis.

\section{Kirjandus}

Altnurme, Lea \& Lyra, Ahti 2004. Tervendamine-misjoneeriv klientkultus. Altnurme, Lea (toim). Mitut usku Eesti: valik usundiloolisi uurimusi. Tartu: Tartu Ülikooli Kirjastus, lk 117-139 (http://www.gbv.de/dms/goettingen/487359925.pdf - 1. detsember 2015).

Džuna = Dzhuna. Wikipedia (https://ru.wikipedia.org/wiki/Джуна - 1. detsember 2015).

Ellermaa, Einar \& Pitsner, Inge 2013. Kaika Laine inimesed: naisest, kes suutis lugeda eluraamatuid. Tallinn: Pilgrim. 
Jahn, Manfred 2005. First person narration. Hermann, David \& Jahn, Manfred \& Ryan, Marie-Lauren (toim). Routledge Encyclopedia of Narrative Theory. London \& New York: Routledge, lk 173-177.

Jõgioja, Heldur 2008. Kaika Lainest Vangani I ja II. Rahvameditsiini varasalv. I-II. Tartu: LeHelMus.

Jõgioja, Heldur 2009-2010. Kaika Lainest Vangani. 3.-5. raamat. Rahvaravi sõnastik I-III. I - 2009, IV - 2009, V - 2010. Tartu: LeHelMus.

Jürgen, Madis 2012. Sünnipäevalaps Kaika Laine. GoTraveli reisikiri (http://reisiajakiri. gomaailm.ee/sunnipaevalaps-kaika-laine/ - 1. detsember 2015).

Kudu, Reet 2009. Kaika Laine - sajandi naine. Kaika kaemus. Tallinn: Kodutrükk.

Kõiva, Mare 1990. Estonskije zagovory. Klassifikatsija i zhanrovye osobennosti. Tallinn: Institut estnoskogo jazyka i literatury. Rukopis. Tallinn.

Kõiva, Mare 1993. Teadja: Laine Roht (05.03.1993). ETV.

Kõiva, Mare 1995. Loitsust riituseni. Hiiemäe, Mall \& Kõiva, Mare (toim). Rahvausund tänapäeval. Tartu: Eesti Keele Instituut, lk 175-194 (http://www.folklore.ee/rl/pubte/ ee/usund/eesti/koiva.pdf - 1. detsember 2015).

Kõiva, Mare 1996. The Transmission of Knowledge among Estonian Witch Doctors. Folklore: EJF 2, lk 77-95 (doi:10.7592/FEJF1996.02.docdoc).

Kõiva, Mare 2015. 20 years of experience bringing together nature religions. Between East and West: Youth, Religion and Politics. Riga: University of Latvia. [Ilmumas.]

Kõivupuu, Marju 2000. Rahvaarstid Võrumaalt: noor ja vana Suri Hargla kihelkonnast. Võru: Võro Instituut (http://www.folklore.ee/pubte/rahvaarstid/ - 30. november 2015).

Ottas, Aita \& Tammer, Tiina 2000. Inimese vägi. Portreelood. Gunnar Aarma, Toomas Tiik, Kaika Laine, Lindmäe Lille, Arno Joala, Luule Viilma, Vigala Sass, Igor Mang. Tallinn: Tänapäev, lk 36-47.

Paju, Aili 1994. Teadjanaine. Tartu: Aili Paju.

Paju, Aili 1998. Karula ravitseja - Kaika Laine. Eesti Loodus 10, lk 474 (http://www. loodusajakiri.ee/eesti_loodus/EL/vanaweb/9810/laine.html - 1. detsember 2015).

Phelan, James \& Booth, Wayne C. 2005. Narrator. Hermann, David \& Jahn, Manfred \& Ryan, Marie-Lauren (toim). Routledge Encylopedia of Narrative Theory. London \& New York: Routledge, lk 388-392.

Poll, Ene (toim) 2004. Eesti nõiad. Tekstid ja fotod ajalehtedest SL Õhtuleht ning Eesti Päevaleht, ajakirjast Kodutohter. Tallinn: Eesti Päevaleht.

Prūse, Inga 2015. Noslēpumiem apvītā leǵenda - dziedniece un pareǵe Džūna. Kas viṇa bija? Džuna. Moja ispoved, 9. juuni (http://www.la.lv/noslepumiem-apvita-legendadziedniece-un-parege-dzuna-kas-vina-bija/ - 1. detsember 2015).

Pärn, Linda 2012. Sensitiivid tänapäeva eesti rahvausundis: nende kujutamine kogumikus "Eesti nõiad”. Käsikirjaline bakalaureusetöö. Tartu: Tartu Ülikool. Kultuuriteaduste ja kunstide instituut, eesti ja võrdleva rahvaluule osakond. 
Život 2015 = Liečitel'ka kremel'ských vládcov: Džuna Davitašvili sama nechápala, aká energia vychádza z jej rúk. Život (http://zivot.cas.sk/clanok/20657/liecitelkakremelskych-vladcov-dzuna-davitasvili-sama-nechapala-aka-energia-vychadza-z-jejruk - 1. detsember 2015).

Tael, Triin 2015. Venemaa leinab Brežnevi imeravitsejat Džunat. Õhtuleht, 9. juuni (http://www.ohtuleht.ee/681009/venemaa-leinab-breznevi-imeravitsejat-dzunat - 1. detsember 2015)

Tender, Tõnu 1992. Tervise andja, kes ei ole loodud keerulistele küsimustele vastajaks [: Laine Roht]. Kultuur ja Elu 5, lk 36-42.

Valtchinova, Galia I. 2007. From Postsocialist Religious Revival to a Socialist Seer and Vice Versa: the remaking of religion in postsocialist Bulgaria. Max Planck Institute for Social Anthropology. Working Paper 98. Halle / Saale: Max Planck Institute for Social Anthropology (http://www.eth.mpg.de/cms/en/publications/working_papers/wp0098. html - 4. detsember 2015).

Veidenberg, Ingrid 2014. Marko Reikop: ma ei taha ettevaatlikult läbi elu hauani hiilida! Eesti Päevaleht, 25. jaanuar (http://epl.delfi.ee/news/lp/marko-reikop-ma-eitaha-ettevaatlikult-labi-elu-hauani-hiilida?id=67677337 -1 . detsember 2015).

\section{Summary}

\section{To a folk healer with a doctor's referral letter}

Mare Kõiva

Keywords: alternative medicine, doctor's note, folk healer, folk medicine, healing rite, Laine Roht

The article discusses one of the healing strategies used by Laine Roht, a well-known folk healer from southern Estonia, in the 1980s; namely, she demanded that the patients turning to her bring a referral letter from their doctor. This kind of behaviour was a response to the state's prohibition of folk medicine methods, and aimed to promote the image that the healer worked in cooperation with professional physicians. These referral letters from medical doctors as well as other written documentation concerned with healing constitute interesting folkloric and psychological research material. The article gives an overview of the healing rituals applied to the patients, diagnoses with which they turned to the healer, the origin of both doctors and patients, and the role of printed materials in the 20th-century healer's tradition and her healing ritual. The author also characterises contemporary media images of healers and the role of the media as basis for the healer's fame. 